\title{
Lithostratigraphy and depositional episodes of the Oligocene carbonate-rich Tikorangi Formation, Taranaki Basin, New Zealand
}

\author{
STEVEN D. HOOD \\ CAMPBELL S. NELSON \\ PETER J. J. KAMP \\ Department of Earth Sciences \\ University of Waikato \\ Private Bag 3105 \\ Hamilton, New Zealand
}

\begin{abstract}
The subsurface Oligocene Tikorangi Formation is a unique and important oil producer in the onshore Waihapa-Ngaere Field, Taranaki Basin, being the only carbonate and fracture-producing reservoir within the basin. Core sample data from seven onshore wells (foredeep megafacies) and a single offshore well (basinal megafacies) are correlated with a suite of sonic and gamma-ray geophysical well log data to derive interpretative carbonate facies for the Tikorangi Formation. Four mixed siliciclasticcarbonate to carbonate facies have been defined: facies Acalcareous siliciclastite ( $<25 \%$ carbonate); facies B-very calcareous siliciclastite $(25-50 \%$ carbonate); facies $\mathrm{C}-$ muddy limestone (50-75\% carbonate); and facies D-coarse limestone (>75\% carbonate). Single or interbedded combinations of these facies form the basis for identifying nine major lithostratigraphic units in the Tikorangi Formation that are correlatable between the eight wells in this study.

The Tikorangi Formation accumulated across a shelfslope-basin margin within a tectonically diversified basin setting, notably involving considerable off-shelf redeposition of sediment into a bounding foredeep. Analysis of gamma, sonic, and resistivity well logs identifies five major episodes of sedimentary evolution. Episode I comprises retrogradational siliciclastic-dominated redeposited units associated with foredeep subsidence. Episode II is a continuation of episode I retrogradation, but with increased mass-redeposited carbonate influx during accelerated foredeep subsidence and relative sea-level rise, the top marking the maximum flooding surface. Episode III involves a progradational sequence comprising relatively pure redeposited carbonate units associated with declining subsidence rates and minimal siliciclastic input, with movement of facies belts basinward. Episode IV consists of prograding aggradation involving essentially static facies belts dominated by often thick, periodically mass-emplaced, carbonate-rich units separated by thin background siliciclastic shale-like units. Episode $\mathrm{V}$ is a retrogradational sequence marking the reintroduction of siliciclastic material into the
\end{abstract}

basin following uplift of Mesozoic basement associated with accelerated compressional tectonics along the AustraliaPacific plate boundary, initially diluting and ultimately extinguishing carbonate production factories and terminating deposition of the Tikorangi Formation.

Keywords carbonate; limestone; geophysical well logs; lithostratigraphy; depositional history; Oligocene; Tikorangi Formation; hydrocarbons; fractured reservoir; Taranaki Basin; New Zealand

\section{INTRODUCTION}

The subsurface Oligocene Tikorangi Formation is a commercially producing carbonate and wholly fracturecontrolled hydrocarbon reservoir within Taranaki Basin, New Zealand (Hood et al. 2002) (Fig. 1A). Although limestone and dolomite form globally important oil reservoirs (McQuillan 1985; North 1985), the Tikorangi Formation is of further interest because it has a non-tropical rather than tropical origin (e.g., Nelson 1978a, 1988; Hood 2000; Hood et al. 2001, 2003 this issue). Moreover, in relation to basin structure, it forms a prominent latest Oligocene reflector horizon on seismic profiles, presently lying 1.5-3.5 km below the Taranaki Peninsula (King \& Thrasher 1996). Producing wells from the formation occur in the onshore WaihapaNgaere Field, discovered in the late 1980s (Fig. 1B,C), and several recently drilled or planned wells have the Tikorangi Formation as a primary or secondary target (Ministry of Commerce 2001).

Previously published work on the Tikorangi Formation is limited and is mainly included as part of more regional studies of Taranaki Basin, such as those by Pilaar \& Wakefield (1978), Palmer (1985), King (1990, 1994), King \& Thrasher (1992, 1996), and Palmer \& Andrews (1993). In particular, the Taranaki Basin geological synthesis by King \& Thrasher (1996) provides excellent background information about Tikorangi Formation set within the context of Taranaki Basin history and petroleum prospectivity more generally. For individual wells, petroleum company openfile well completion reports (based mainly on mudlog cuttings) provide useful data about formation depths, thicknesses, and general lithology. Those for Waihapa-2 (Carter et al. 1988), Waihapa-4 (Carter \& Kelly 1989a), Waihapa-6/6A (Carter \& Kelly 1989b), Ngaere-2 (Petrocorp Exploration Limited 1995), Toko-1 (Adams et al. 1980), Hu Road-1/1A (New Zealand Oil \& Gas 1992), and Maui-1 (Jonkers et al. 1969) are relevant to the present study.

Earlier work has established two broad facies for the Tikorangi Formation. In the subsurface of the eastern onshore region of Taranaki Basin, the formation has been ascribed to a redeposited outer shelf/slope facies (Simpson 1992), renamed by Hood (2000) the foredeep megafacies (Fig. 2, 3; Table 1), which consists of predominantly muddy to 


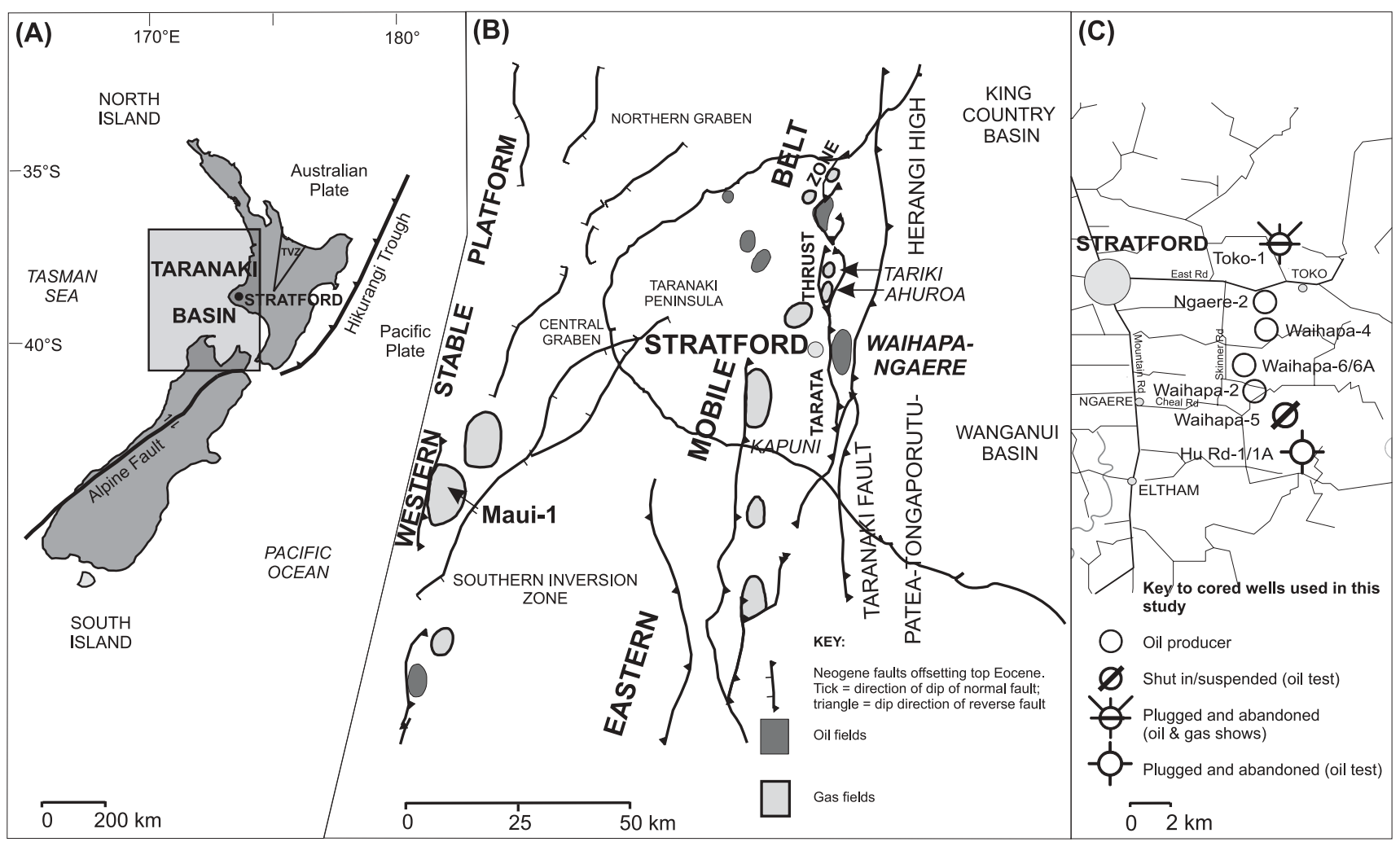

Fig. 1 A, Location of Taranaki Basin, New Zealand. TVZ, Taupo Volcanic Zone. B, Major structural and tectonic elements and main oil/condensate accumulations within Taranaki Basin, including the Waihapa-Ngaere and Maui Fields. Adapted from King \& Thrasher (1996). C, Location and current status of the seven onshore wells providing core from the Tikorangi Formation within the WaihapaNgaere Field that form the basis for this study.

sometimes sparry limestone with thinner interbedded units of fine calcareous sandstone, siltstone, and claystone. Palmer (1985) previously described this megafacies as a deep-water bioclastic limestone, while Simpson (1992) and King \& Thrasher (1996) suggested the limestone often consists of reworked bioclastic material deposited at outer shelf to upper slope depths. Offshore to the west and north of the Taranaki Peninsula lies a bathyal facies (Simpson 1992), renamed the basinal megafacies by Hood (2000) (Fig. 2, 3; Table 1). It consists of calcareous siliciclastite (siltstone, mudstone) that is largely tectonically undisturbed. These end-member megafacies appear to span different age ranges. The foredeep megafacies has been assigned to the early Waitakian New Zealand Stage (Morgans 1985). Historically, this stage has fluctuated from being entirely within, to partly within, to wholly younger than, the Oligocene (Nelson et al. 2001). Here we adopt the most recent strontium isotope age estimates made by Nelson et al. (2001) for the base and top of the Waitakian Stage at c. 25.5 and 22.2 Ma, respectively. On this basis, the early Waitakian (c. 25.5-23.8 Ma) sits within the latest Oligocene, whose boundary with the Miocene was set at 23.8 Ma by Berggren et al. (1995). The more distal basinal megafacies has been dated by Scott (1985) as ranging from Whaingaroan to Waitakian (early Oligocene to earliest Miocene), but with most of the Tikorangi Formation suggested to be also of early Waitakian age (latest Oligocene).

Despite the economic significance of the Tikorangi Formation, it remains poorly understood in a sedimentary geological context compared to age-equivalent non-reservoir- bearing temperate limestone exposed in onland New Zealand (Nelson 1978a). Limitations on information for the Tikorangi Formation arise from a lack of outcrop, the uneven spatial distribution of cored wells, and the absence of any complete core coverage through the formation, so that only isolated "windows of opportunity" exist for studying the limestone. It is this shortcoming that we address in this paper, focusing attention on the Tikorangi Formation in eight wells for which some core sample is available-seven from onshore eastern Taranaki (Toko-1, Ngaere-2, Waihapa-2, -4, -5, and -6, and $\mathrm{Hu}$ Road-1; Fig. 1C), representative of the foredeep megafacies, and one (Maui-1; Fig. 1B, 3) from offshore western Taranaki Basin in the basinal megafacies.

Within the above constraints of core material availability, a primary aim is to attempt to establish a detailed lithostratigraphic framework for the entire Tikorangi Formation based upon geophysical well log characteristics of the formation. Well log data provide the only nearcomplete data records available for the entire formation interval. Integration of sonic (Dt) and gamma-ray (GR) well $\log$ data with laboratory-derived data from core samples provides the basis for establishing a comprehensive lithostratigraphy for the formation. While this stratigraphy is locally complex, it seemingly includes correlatable units throughout the Waihapa-Ngaere Field.

While analysis of geophysical log data is neither easy nor unambiguous (Emery \& Myers 1996), and the pitfalls of a focused well log study are appreciated, here we attempt to identify and interpret the geophysical and lithological log patterns through the Tikorangi Formation in the study wells 
Fig. 2 Schematic lithostratigraphy for the Tikorangi Formation in Taranaki Basin showing age comparison of the early Oligocene to latest Oligocene (Lwhearly Lw) basinal megafacies and latest Oligocene (early Lw) foredeep megafacies. The carbonaterich Tikorangi Formation sits unique amongst otherwise siliciclastic-dominated deposits. See Fig. 3 for well locations. New Zealand biostratigraphic stages are: Ar, Runangan; Lwh, Whaingaroan; Ld, Duntroonian; Lw, Waitakian; Po, Otaian; Pl, Altonian.

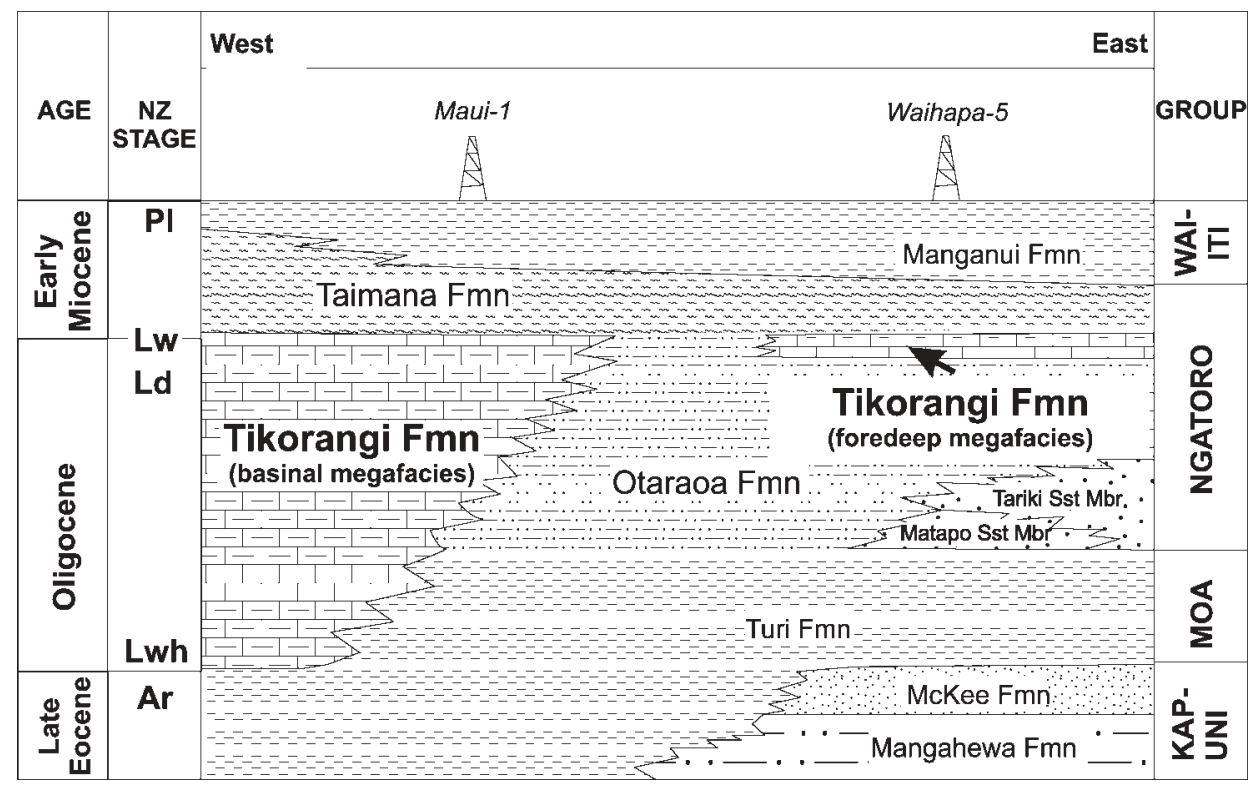

as a basis for unravelling a broad-scale depositional history for the formation. Sarg \& Lehmann's (1986) pioneering work on carbonates in Texas and Mexico showed how carbonate shelves and ramps retrograded, aggraded, and prograded in apparent response to variations in sea level. While well log patterns within the Tikorangi Formation have been of interest to workers within the petroleum industry (e.g., T. Russell pers. comm. 1999), we are unaware of any attempts to unravel their depositional significance. Small-scale stratigraphic units (e.g., coarsening- or fining-upward cycles) are widely accepted to be important in hydrocarbon reservoir studies (Harris et al. 1999). Such cycles or sets of cycles may

Table 1 Comparative properties of the Tikorangi Formation foredeep and basinal megafacies. Lwh, Whaingaroan; Lw, Waitakian.

\begin{tabular}{|c|c|c|}
\hline Property & Foredeep megafacies & Basinal megafacies \\
\hline Age & $\begin{array}{l}\text { Latest Oligocene } \\
\text { (early Lw) }\end{array}$ & $\begin{array}{l}\text { Early Oligocene to latest } \\
\text { Oligocene (Lwh-early Lw) }\end{array}$ \\
\hline Colour & $\begin{array}{l}\text { Typically grey to buff to white, but occasionally } \\
\text { olive to brown often becoming darker with depth }\end{array}$ & $\begin{array}{l}\text { Generally light brown } \\
\text { to dark grey/green }\end{array}$ \\
\hline Lithology & $\begin{array}{l}\text { Typically muddy (increasing towards base) } \\
\text { limestone with lesser coarser fine sandy limestone } \\
\text { interbedded with calcareous } \\
\text { mudstone/siltstone and sandstone }\end{array}$ & $\begin{array}{l}\text { Calcareous to very calcareous } \\
\text { mudstone }\end{array}$ \\
\hline Classification & $\begin{array}{l}\text { Generally packstone with lesser (poorly washed) } \\
\text { grainstone or wackestone, rare mudstone }\end{array}$ & $\begin{array}{l}\text { Generally wackestone with } \\
\text { lesser mudstone }\end{array}$ \\
\hline Bedding & $\begin{array}{l}\text { Commonly highly bioturbated, often interbedded } \\
\text { with calcareous siltstone or mudstone } \\
\text { and occasionally sandstone }\end{array}$ & $\begin{array}{l}\text { Massive to well bedded, } \\
\text { occasionally interbedded with } \\
\text { calcareous shale and siltstone }\end{array}$ \\
\hline $\begin{array}{l}\text { Biogenic } \\
\text { structures }\end{array}$ & $\begin{array}{l}\text { Heavily bioturbated, rare parallel } \\
\text { bedding preserved }\end{array}$ & Rare biogenic structures \\
\hline Bioclasts & $\begin{array}{l}\text { Planktic foraminifera, echinoderms, } \\
\text { bivalves, calcareous red algae, } \\
\text { barnacles, bryozoans, coccoliths }\end{array}$ & $\begin{array}{l}\text { Common to abundant planktic } \\
\text { foraminifera, coccoliths }\end{array}$ \\
\hline Siliciclasts & $\begin{array}{l}\text { Generally includes fine } \\
\text { quartz/feldspar sand and often lithic } \\
\text { fragments, minor clay }\end{array}$ & $\begin{array}{l}\text { Commonly silt-sized quartz } \\
\text { with lesser feldspar }\end{array}$ \\
\hline $\begin{array}{l}\text { Authigenic/ } \\
\text { other }\end{array}$ & $\begin{array}{l}\text { Rare pyrite and/or carbonaceous } \\
\text { flecks, often glauconitic }\end{array}$ & $\begin{array}{l}\text { Rare carbonaceous flecks and pyrite, } \\
\text { glauconite increasing towards base }\end{array}$ \\
\hline Hardness & $\begin{array}{l}\text { Generally hard, dense, strongly } \\
\text { pressure-dissolved and cemented, } \\
\text { no porosity }\end{array}$ & $\begin{array}{l}\text { Generally hard, dense, well- } \\
\text { cemented, no porosity }\end{array}$ \\
\hline Cementation & $\begin{array}{l}\text { Macro- to microcrystalline calcite } \\
\text { with some dolomite }\end{array}$ & Micro- to cryptocrystalline calcite \\
\hline Fractures & $\begin{array}{l}\text { Extensive and complex calcite/dolomite } \\
\text { partly filled fracture systems }\end{array}$ & Absent \\
\hline
\end{tabular}




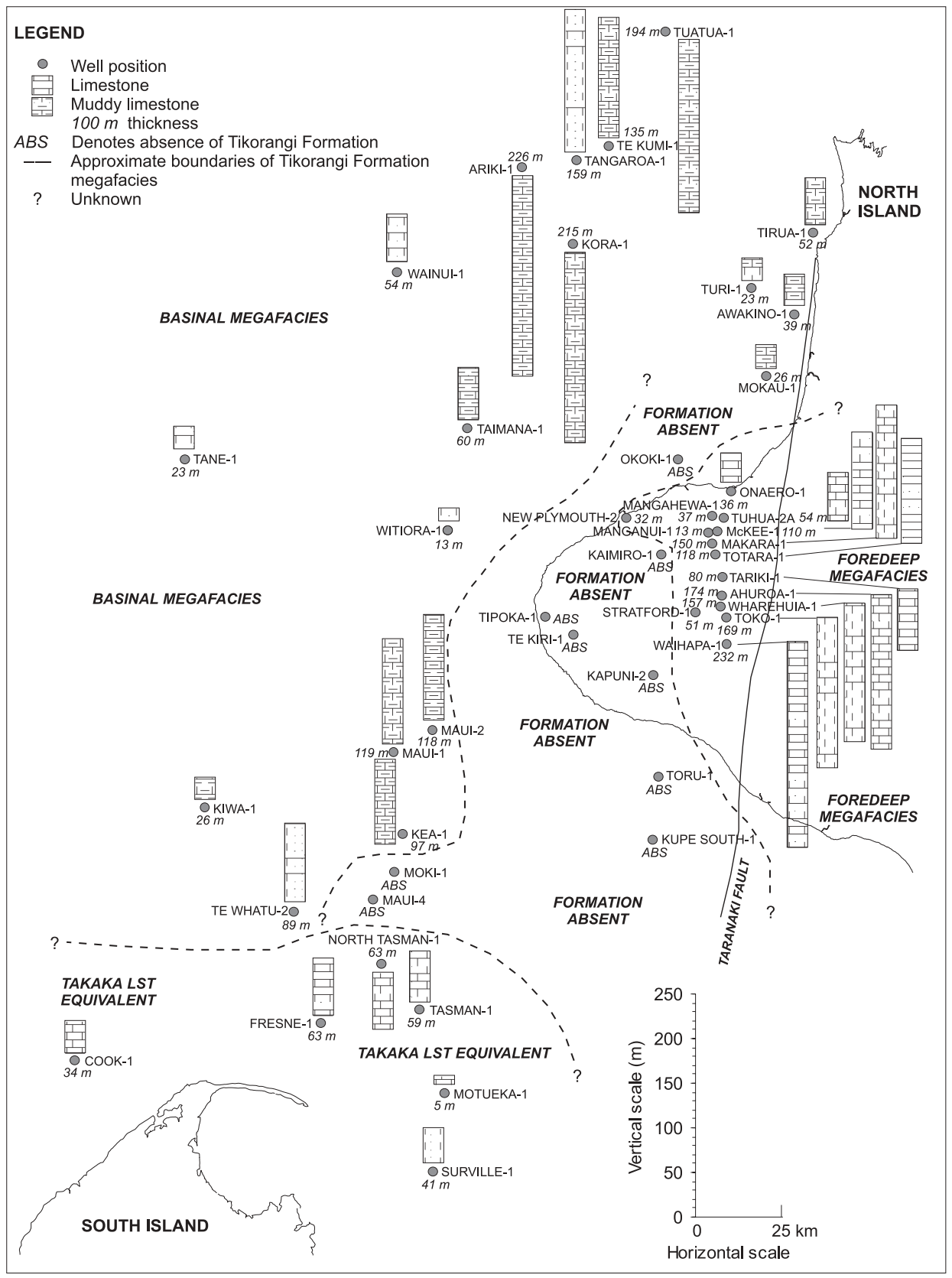

Fig. 3 The occurrence, thickness, and megafacies of the Tikorangi Formation in selected wells, Taranaki Basin. Data compiled from Simpson (1992), King \& Thrasher (1996), and unpublished well completion reports.

frequently equate with flow units or best fracture-producing units in a reservoir. Subdividing the Tikorangi Formation into smaller units or sedimentary episodes, and correlating them, has facilitated a better understanding of the depositional history and processes affecting the formation. This has enabled some general inferences to be drawn about possible depositional controls and mechanisms. Appendix 1 is a flowchart illustrating the often complex interrelationships of the major geological elements defined and discussed here for the Tikorangi Formation, and in Hood et al. (2003).

\section{GEOLOGICAL SETTING}

The sedimentary and tectonic evolution of Taranaki Basin, although complex, has been divided by King \& Thrasher
(1996) into three main periods of development: Period ILate Cretaceous-Paleocene intra-continental extensional rifting; Period II-Eocene to earliest Oligocene passive margin setting; and Period III-Oligocene-Recent active marginal basin associated with evolution of the AustraliaPacific convergent plate boundary through New Zealand (Fig. 1A). During this latter phase, the basin became separated into two contrasting tectonic settings-an active eastern zone (Eastern Mobile Belt) and a passive western zone (Western Stable Platform) (Fig. 1B). The onset of Period III was marked by comparatively sudden and rapid subsidence in the late early Oligocene, possibly related to development of a proto-transform plate boundary through New Zealand initiating a rapid basinwide marine transgression (Stern \& Davy 1990; King \& Thrasher 1992, 1996; Holt \& Stern 1994; Nelson et al. 1994; Stern \& Holt 1994). This subsidence was 
A

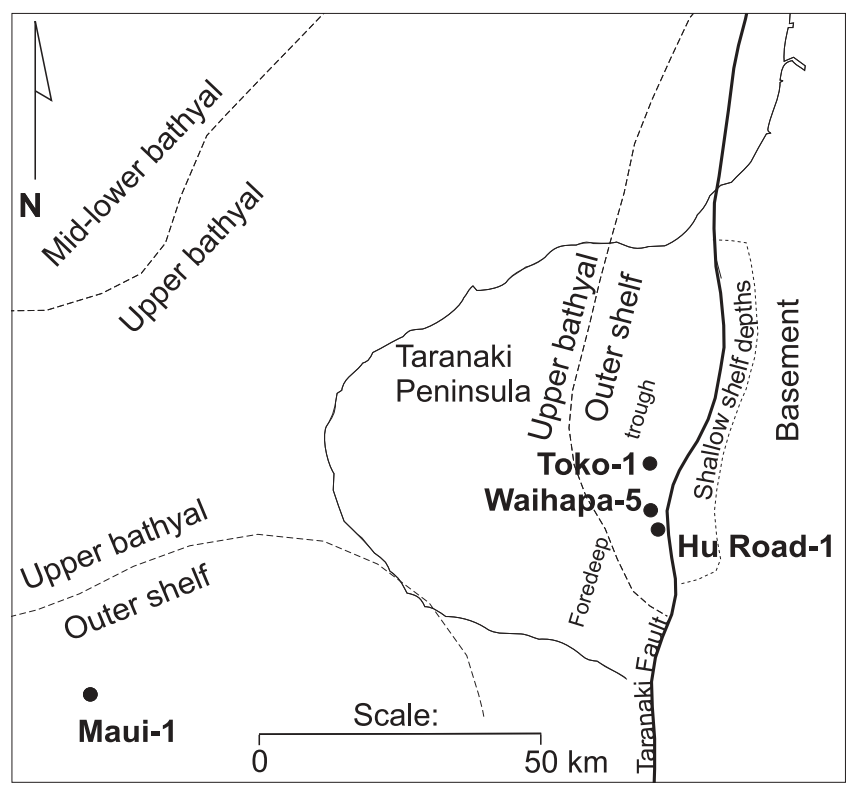

B

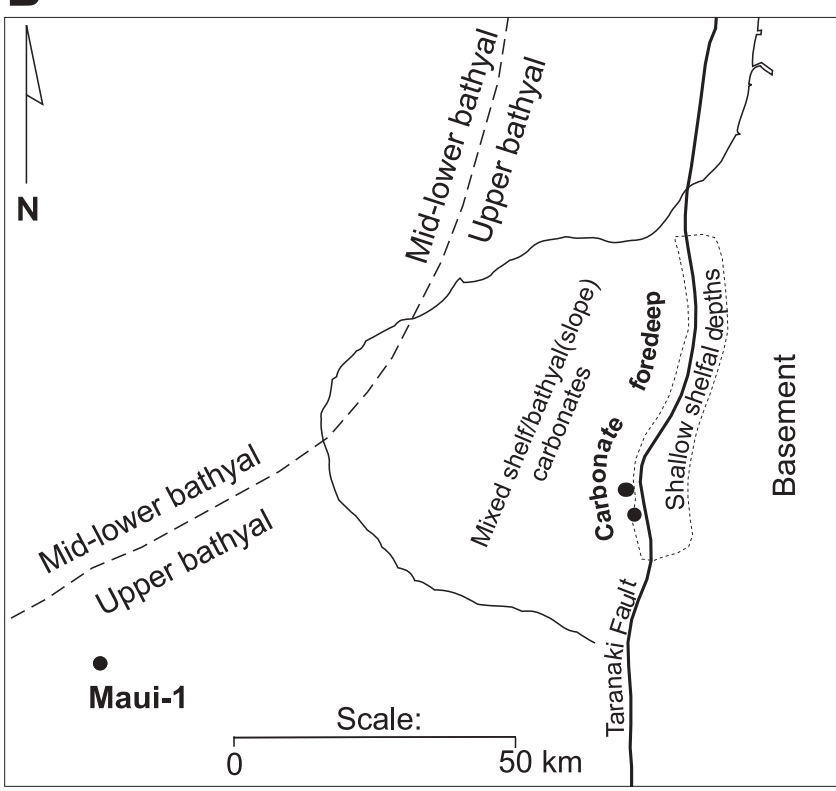

Fig. 4 Paleogeographic changes for the central eastern Taranaki Basin margin from (A) the mid-Oligocene to (B) latest Oligocene/ earliest Miocene during deposition of the Tikorangi Formation basinal (Maui-1) and foredeep (Waihapa-5) megafacies. Developed from conceptual reconstructions suggested by Simpson (1992), Palmer (1995), King \& Thrasher (1996, fig. 5.5), and Mauri et al. (1999). Selected study wells are shown in their current position, although units encountered in these wells are allochthonous in nature and have been thrust eastwards from their original positions.

especially pronounced along the basin's eastern margin where an asymmetric trough developed west of the Taranaki Fault and accumulated the latest Oligocene (Waitakian, Lw) Tikorangi Formation foredeep megafacies (Fig. 3) underlain by calcareous siltstone and mudstone of the Otaraoa Formation. All but southern areas of Taranaki Basin had reached bathyal depths by this time (Fig. 4), while paleolatitudes of the basin more generally were c. $45-50^{\circ} \mathrm{S}$ (Nelson \& Cooke 2001). In the west, sequences of the laterally equivalent basinal megafacies of the Tikorangi Formation accumulated from early Oligocene to earliest Miocene (Fig. 2, 3). The Tikorangi rocks are overlain by calcareous mudstone and marl of the Taimana Formation, reflecting an increased siliciclastic supply to the basin due to uplift of source rock areas.

During the early Miocene, onset of horizontal compression resulted in the Taranaki Fault and associated Tarata Thrust Zone becoming the mobile western edge of a zone of contraction (Eastern Mobile Belt; Fig. 1B) that formed in the basin behind the newly active subduction zone off eastern North Island. A change from carbonate- to siliciclasticdominated sedimentation occurred as a result of basement thrusting from the east, and uplift provided a source for an increased siliciclastic supply (Fig. 2) that initiated a still continuing regressive phase of sedimentation in Taranaki Basin (King \& Thrasher 1996; Kamp et al. 2002). The associated series of overthrust structures, in which the Waihapa-Ngaere wells in this study are sited, were instrumental in formation of the fractured reservoir comprising the Tikorangi foredeep megafacies (Hood et al. 2002). West of the Eastern Mobile Belt, the Western Stable Platform remained comparatively unaffected by the compressive tectonic events, and is the setting for Maui-1 well, representative of the offshore basinal megafacies (Fig. 1B).

\section{STRATIGRAPHIC BACKGROUND}

Many of the lithostratigraphic names applied to the Tikorangi rocks encountered in drilling within Taranaki Basin were historically adopted from adjoining onshore areas, particularly King Country Basin (Fig. 1B). This has resulted in inconsistent and often ambiguous nomenclature for the formation, so that, for example, the different names Cobden Limestone, Te Kuiti Group or Limestone, and Tikorangi Limestone (e.g., Simpson 1992) have been used extensively within petroleum company well completion reports, despite formalisation of the name Tikorangi Formation by Palmer (1985). The name Tikorangi was first used by van Rijen \& van der Abeele (1963) for the $37 \mathrm{~m}$ thick interval comprising sandy limestone, calcareous sandstone, and white crystalline limestone interbedded with calcareous mudstone from 3213 to 3250 metres along hole (mAH) depth in Mangahewa-1 well, drilled in 1960 east of New Plymouth (Fig. 3). Subsequently, the perceived predominance of limestone in the Tikorangi led to widespread use of the term Tikorangi Limestone for the formation. However, we will show later that there is a wide range of carbonate contents in the formation and values often drop below $50 \% \mathrm{CaCO}_{3}$. Until more core and analytical data are available, we prefer to use Palmer's (1985) formal name Tikorangi Formation for this carbonate-rich unit, but accept the usefulness of informal terms such as Tikorangi limestone, Tikorangi carbonate, and Tikorangi megafacies.

Tikorangi Formation lies between two calcareous, but generally siliciclastic-dominated units-Otaraoa Formation below, comprising calcareous sandstone and siltstone, and Taimana Formation above, consisting of calcareous mudstone and marl (Fig. 2). The Otaraoa, Tikorangi, and Taimana Formations together form the Ngatoro Group, a name 
proposed by King (1988a,b) for this succession of generally calcareous Oligocene to early Miocene rocks, analogous to the age-equivalent Te Kuiti (Mahoenui) Group(s) onshore in King Country Basin (Fig. 1B) (Nelson 1978b; Nelson \& Hume 1987).

The lower boundary of Tikorangi Formation in wells has previously been defined in petroleum reports (e.g., Simpson 1992) by well log character and is placed at a noticeable increase in sonic velocity and resistivity, which is mirrored by a decrease in GR values. The responses reflect a generally gradational change from the more argillaceous and silty nature of the underlying Otaraoa Formation (Palmer 1985; King \& Thrasher 1996) to limestone-bearing beds of the Tikorangi Formation (summary columns in Hood 2000). The log appearance of the upper boundary of the Tikorangi Formation usually corresponds with a relatively sharp decrease in sonic velocity and resistivity, and a corresponding increase in GR, upon entering the siltstone and fine sandstone of the Taimana Formation.

Stick columns have been constructed in Fig. 3 to show the presence or absence of the Tikorangi Formation at well sites throughout Taranaki Basin, and the thickness and general lithology of the formation. In the eastern onshore region of the basin, the foredeep megafacies tends to thicken southwards from Turi-1 $(23 \mathrm{~m})$ in the north of the basin to reach a maximum thickness in the Toko and Waihapa areas (c. $240 \mathrm{~m}$ ), coinciding with the eastern side of the foredeep trough (Fig. 3, 4), and then thins to the west. The formation is absent (either not deposited or eroded) in western onshore Taranaki Peninsula and in the offshore area immediately adjacent and south encompassed by Maui-4, Moki-1, KupeSouth-4, Toru-1, Kapuni-2/13, Te Kiri-1, and Tipoka-1 wells (Fig. 3). The limestone is also absent farther north at Kaimiro1 and Okoki-1. Farther west, the basinal megafacies characterises offshore areas of Taranaki Basin (Fig. 3). The offshore sections are condensed, typically only c. 20-30 m thick, but become better developed and thicker (to $>200 \mathrm{~m}$ to reach $226 \mathrm{~m}$ at Ariki-1) in the north of the basin. In the far southwest corner of the basin, in the Cook-1, Fresne-1, Surville-1, Tasman-1, and North Tasman-1 wells, is the ageequivalent Takaka Limestone (Leask 1980), a thin (generally $<60 \mathrm{~m}$ ), inner shelf lateral equivalent to the Tikorangi Formation. Other exposed onland age equivalents include the widespread shelf carbonates of the Te Kuiti Group in the adjacent King Country Basin of North Island (Fig. 1B), documented by Nelson (1973, 1978b). The younger Otorohanga Limestone, like the Tikorangi Formation, is latest Oligocene (Waitakian) in age and is typically a very pure shelfal limestone unit up to $60 \mathrm{~m}$ or more in thickness.

\section{DRILL CORE}

The focus of attention for the Tikorangi Formation has been in the onshore oil-producing series of wells (Tariki, Ahuroa, Waihapa, Ngaere) forming the Waihapa-Ngaere Field (Fig. 1B). This field has provided a disproportionately large amount of conventional core material from a very localised area in relation to the known basinwide extent of the limestone (Fig. 3). Five wells in the field (Waihapa-2, -4, -5 , -6, and Ngaere-2; Fig. 1C) have been cored discontinuously, giving a total of c. $368 \mathrm{~m}$ of drill core-the raw sample base for the present study. Figure 5 shows the disparity between the thickness of Tikorangi Formation in

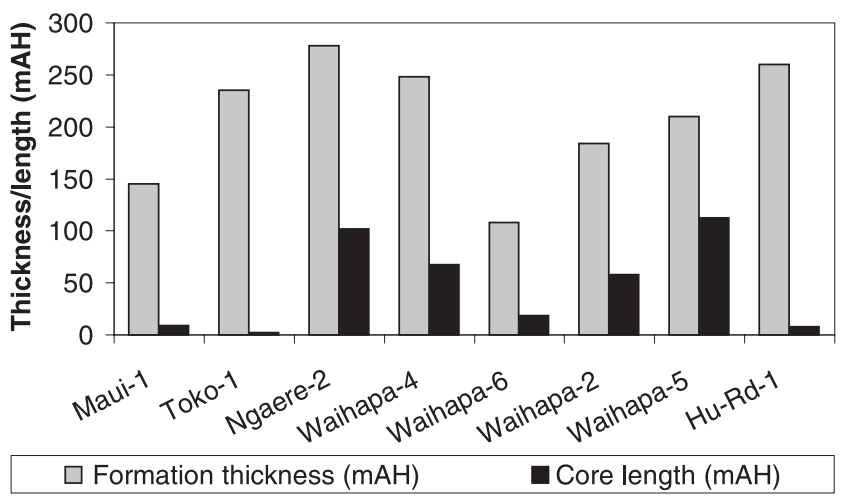

Fig. 5 Histograms showing the difference between the thickness of the Tikorangi Formation in each of the cored wells versus the actual core length drilled and available for sampling. $\mathrm{mAH}$, metres along hole.

each of the cored wells versus the actual length of core obtained. A paucity of core exists away from the WaihapaNgaere Field. The only other core material available within the onshore foredeep megafacies of the Tikorangi Formation is from two wells located very near the Waihapa-Ngaere Field wells, namely Hu Road-1A and Toko-1 (Fig. 1C). For the offshore basinal megafacies, c. $9 \mathrm{~m}$ of conventional core is available from the offshore Maui-1 well (Fig. 1B).

\section{METHODS}

A representative suite of 236 samples of Tikorangi Formation was collected from cores held in the Ministry of Commerce Core Library, Gracefield, Lower Hutt. Information relating to drill core numbers, subsurface depths, percent recovery, and other core statistics, including a sample catalogue of core samples used in this study, are given in Hood (2000). Total carbonate percentage values were determined by acid digestion for a selection of 74 of these samples. The carbonate represents the sum of calcite and/or dolomite in samples. Petrographic (compositional and textural) properties were determined as part of a parallel petrologic study of the formation (Hood 2000). Where appropriate, some of these data are presented here and are reported fully by Hood et al. (2003).

Geophysical log data were provided for the eight study wells by Petrocorp Exploration Ltd, now Shell Petroleum and Mining Company Ltd. Sonic (or Dt) logs were available for all wells except Hu Road-1A, in which no sonic logs were run. The Dt value $(\mu \mathrm{s} / \mathrm{ft}$ ) is the two-way travel time, and the lower this value the higher is the sonic velocity of the core sample. GR logs (American Petroleum Institute unit) and a suite of resistivity $\operatorname{logs}$ (LLS-Laterolog shallow, LLD_Laterolog deep (ohms $\left.\mathrm{m}^{2} / \mathrm{m}\right)$ ) were also available for all wells. A GR log for the original Hu Road-1 well has been used as a surrogate for the Hu Road-1A sidetrack. The suite of geophysical logs typically provides measurements at $0.125 \mathrm{mAH}$ intervals throughout Tikorangi Formation (Fig. 6).

Correlation of laboratory-derived carbonate percentage and petrographic data with both Dt and GR geophysical log data was conducted using linear regression analysis. The degree of correlation between the two pooled datasets was 
Fig. 6 Geophysical logs for the Tikorangi Formation in the Waihapa-Ngaere Field. Top and baselines for the formation are shown. GR, gamma-ray log (API); Dt, sonic $\log (\mu \mathrm{s} / \mathrm{ft}) ; \mathrm{ILD} / \mathrm{LLD}$, resistivity $\log$ (ohms $\mathrm{m}^{2} / \mathrm{m}$ ). Dashed line separates generally more subdued lower log division from upper more erratic, often spiky $\log$ division. All $\operatorname{logs}$ are drawn to scale in metres along hole $(\mathrm{mAH})$. No horizontal scale is implied in relation to well positions.

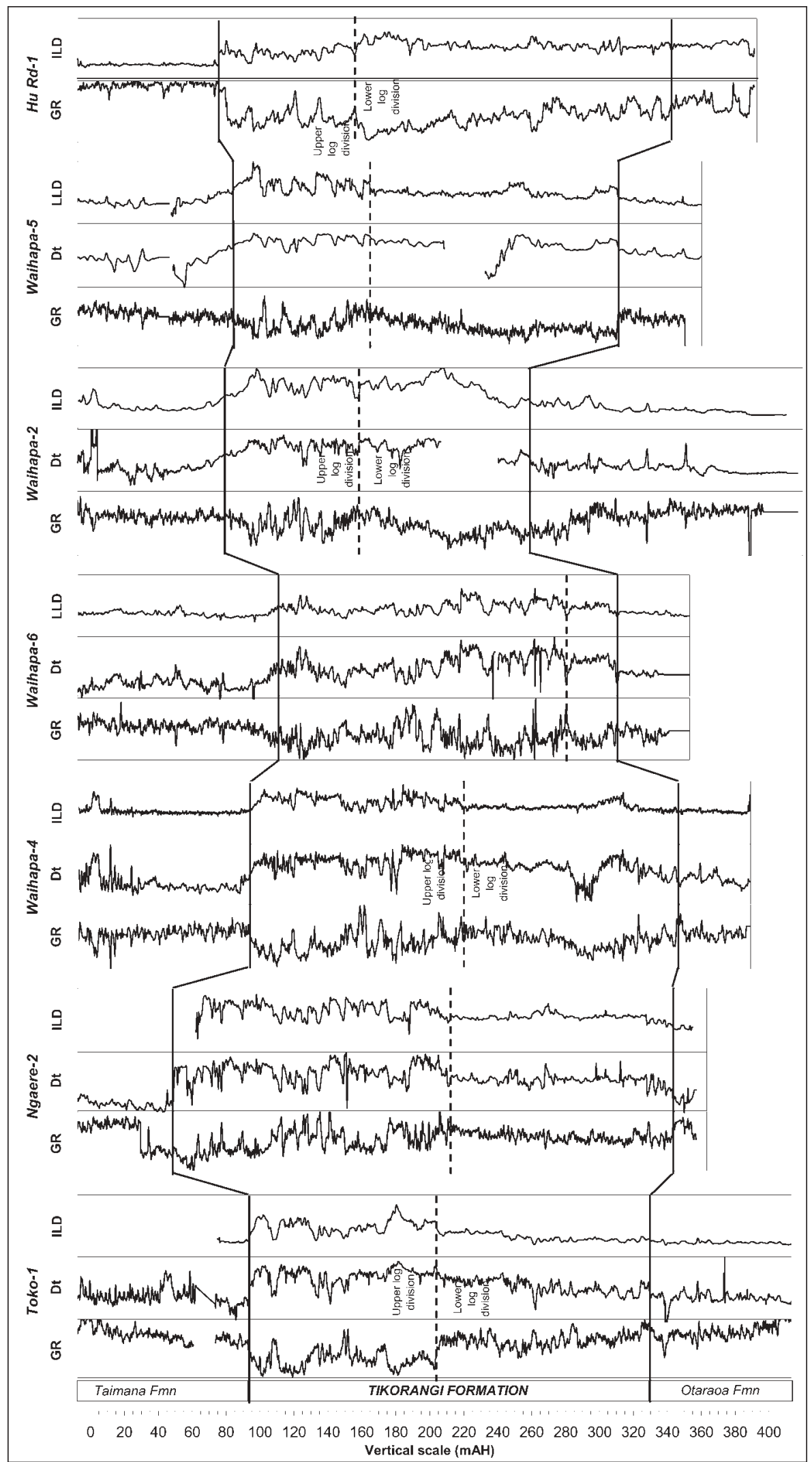




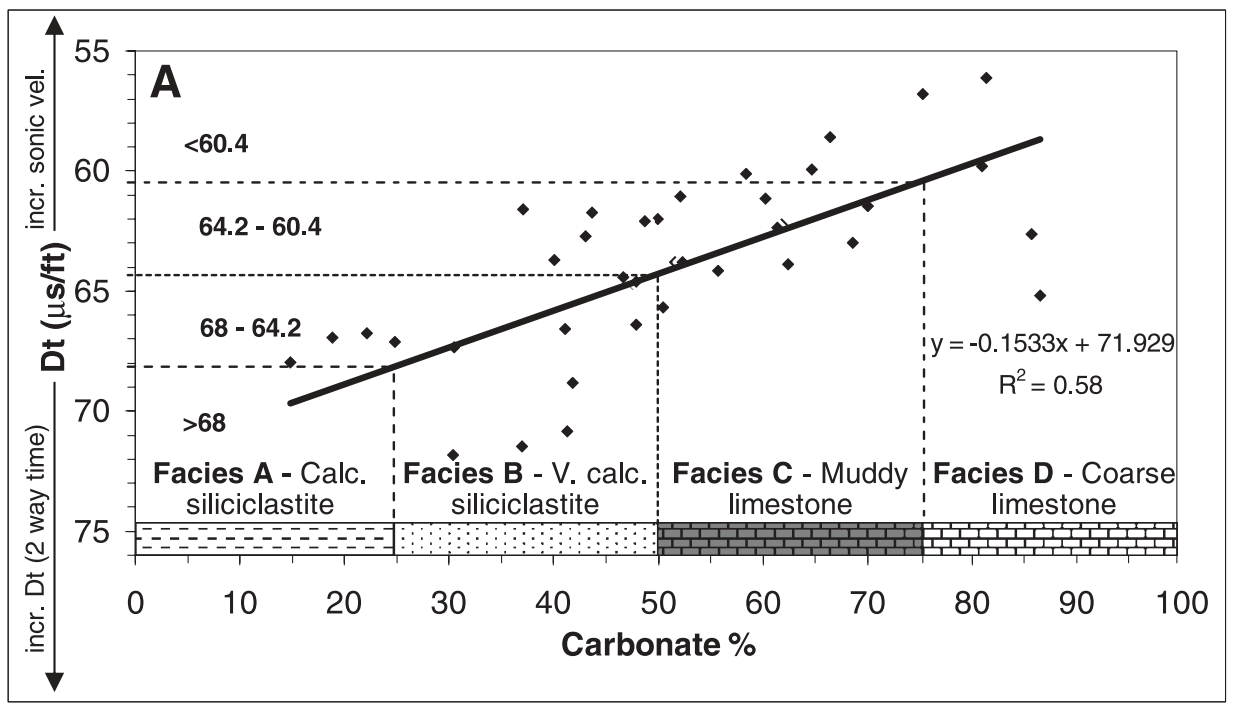

Fig. 7 Relationship diagrams between laboratory carbonate data and corresponding (A) sonic velocity (Dt) and $(\mathbf{B})$ gamma-ray (GR) values from geophysical logs. The correlation lines shown have been used to construct a complete carbonate lithostratigraphy for the entire Tikorangi Formation at each well site (see Fig. 8). Carbonate-based facies A$\mathrm{D}$ are shown along the base of the diagrams. Calc., calcareous; V., very; incr., increasing.

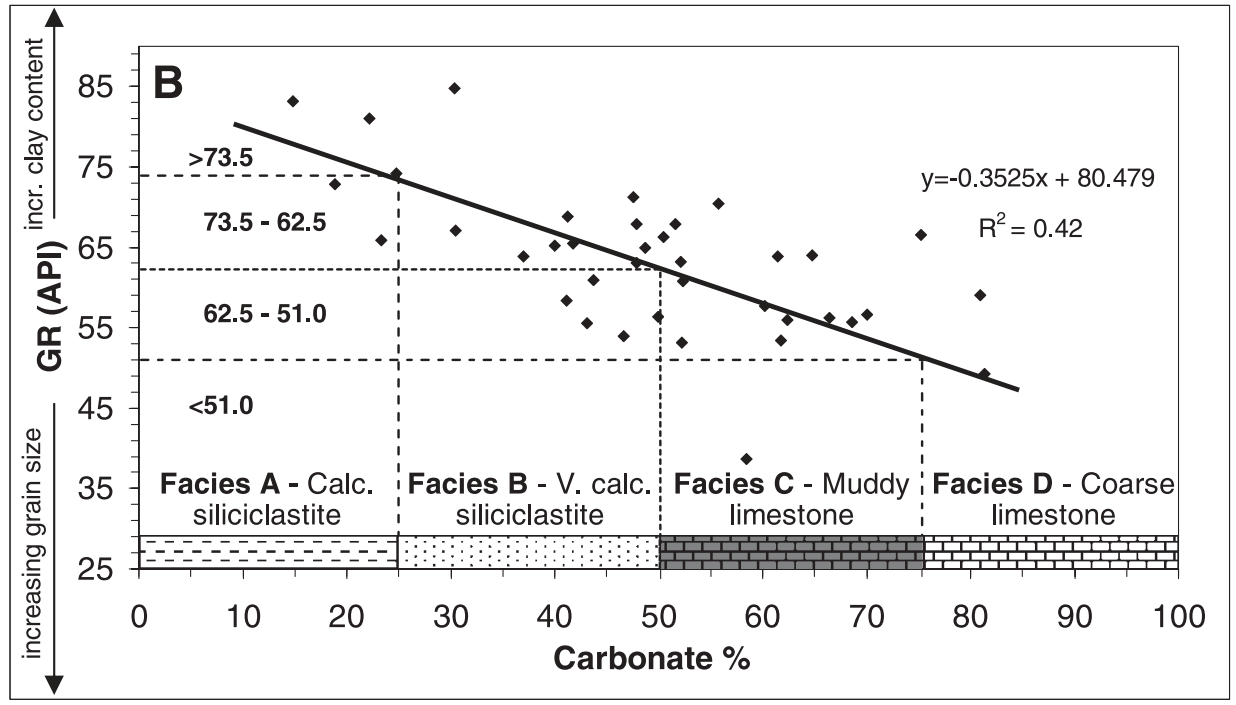

determined using $R$-squared values performed using a transformed regression model on linear trendlines. All data supporting this study are contained in Hood (2000) and are available on $\mathrm{CD}$ on request.

\section{LITHOSTRATIGRAPHY}

\section{Carbonate data}

Carbonate percentage data for the analysed Tikorangi Formation samples range from c. 15 to $100 \%$, with an average content of 53\% (Fig. 7). About one-half of the analysed samples contain $<50 \%$ carbonate. Strictly, therefore, these are not limestone (Scoffin 1987), but rather are calcareous siliciclastic rocks, or calcareous siliciclastite. Samples of the basinal megafacies from Maui-1 have carbonate values ranging from 32 to $41 \%$, while samples from onshore $\mathrm{Hu}$ Road-1 include the purest limestone, containing up to almost $100 \%$ carbonate. Waihapa, Ngaere, and Toko well cores show a wide range in carbonate values (15-86\%) that can change rapidly over short distances. Overall, an up-core increase in carbonate content characterises the Tikorangi Formation (Fig. 8).

\section{Carbonate-well log relationships}

Trends in Dt and GR values with changing rock properties for all the combined sample pool are summarised in Fig. 9. With decreasing Dt value, more competent and better cemented rocks are correlated with a general linear increase in carbonate content, reflecting cleaner and generally coarser units with higher bioclastic and spar cement contents, and lower siliciclastic and matrix contents. Trends are opposite for GR results (Fig. 9). As GR increases, or the shaliness increases, grain size generally decreases, with linearly increasing matrix (clay) and siliciclastic contents, and decreasing bioclastic content. More specifically, the best correlation was achieved for both Dt and GR versus carbonate content (Fig. 7), which shows an increase with reducing Dt value and decreasing GR (clay mineral abundance). The relationships shown have enabled continuous carbonate logs to be derived for all eight wells in this study (Fig. 8).

The carbonate data provide the most useful basis for establishing a meaningful lithostratigraphy within this spectrum of carbonate-rich to carbonate-poor lithologies. To do this, lines delineating carbonate values of 25,50 , and $75 \%$ were drawn on both the Dt and GR plots so as to define four 
Fig. 8 Carbonate logs derived for the eight study wells using the well $\log$ data/carbonate data correlations in Fig. 7. Data points are smoothed over eight $0.125 \mathrm{~m}$ intervals to give a moving average of $1 \mathrm{~m}$. Logs are drawn to the same scale with depth shown as metres along hole (mAH). The base and top of the Tikorangi Formation labelled are those suggested in this study (Table 2). Logs are extended into underlying and overlying Otaraoa and Taimana Formations, respectively, to show the frequently marked changes in carbonate composition from the Tikorangi Formation. Gaps in the carbonate logs result from missing geophysical log data.

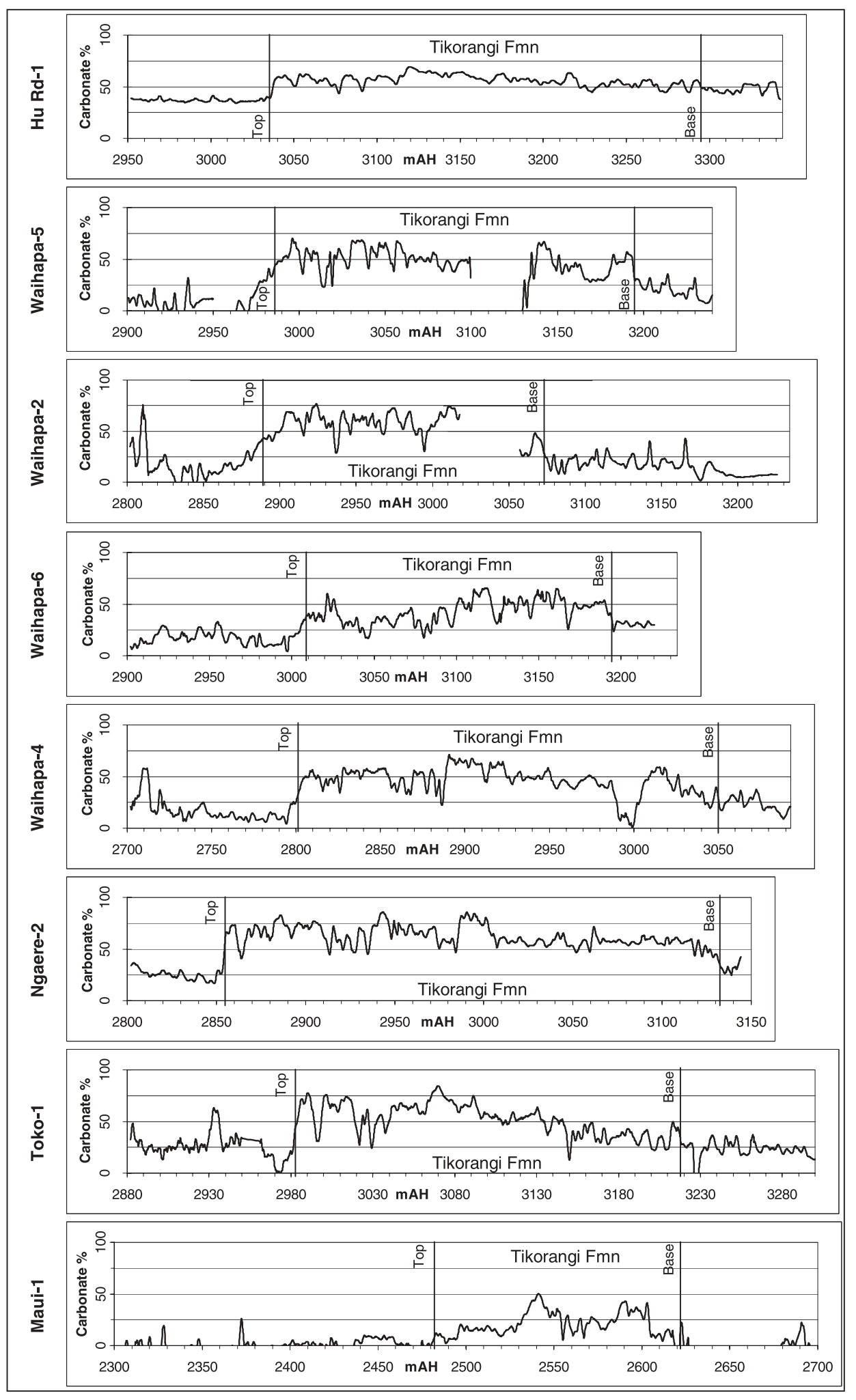

major carbonate facies: facies A, $<25 \%$ carbonate; facies $\mathrm{B}$, 25-50\% carbonate; facies C, 50-75\% carbonate; and facies D, >75\% carbonate (Fig. 7; Appendix 1). Knowing the limiting values of Dt and GR for the four facies, it is possible to erect interpretative lithostratigraphic logs in terms of these facies for the Tikorangi Formation in all wells, summarised here as a panel diagram (Fig. 10). By way of example, a full stratigraphic log is illustrated for Ngaere-2 well in Fig. 11. Comparable stratigraphic sections for all the other study wells are given in Hood (2000) and are available on CD on request. 


\begin{tabular}{|c|c|c|c|c|}
\hline ROCK PROPERTY & $\begin{array}{c}\text { As rock } \\
\text { property } \\
\text { increases by } \\
25 \% \text { sonic }\end{array}$ & $\begin{array}{c}\text { Magnitude of } \\
\text { Dt value } \\
\text { change }(\mu \mathrm{s} / \mathrm{ft})\end{array}$ & \begin{tabular}{|c|} 
As rock \\
property \\
increases by \\
$25 \%$ GR \\
\end{tabular} & $\begin{array}{c}\text { Magnitude of } \\
\text { GR change } \\
\text { (API) }\end{array}$ \\
\hline $\begin{array}{l}\text { Total carbonate \% } \\
\text { Whole rock composition } \\
\text { Total bioclast \% } \\
\text { Total siliciclast \% } \\
\text { Micrite/Matrix \% } \\
\text { Spar cement \% } \\
\text { Bioclastic composition } \\
\text { Bivalves \% } \\
\text { Echinoderms \% } \\
\text { Benthic forams \% } \\
\text { Planktic forams \% } \\
\text { Calcareous algae \% } \\
\text { Spicules and spines \% } \\
\text { Siliciclastic composition } \\
\text { Quartz \% } \\
\text { Feldspar \% } \\
\text { Glauconite \% } \\
\text { Texture } \\
\text { Maximum skeletal grain size } \\
\text { Mean skeletal grain size } \\
\text { Maximum siliciclastic grain size } \\
\text { Mean siliciclastic grain size }\end{array}$ & $\begin{array}{l}\longrightarrow \\
- \\
-\end{array}$ & $\begin{array}{l}* 10 \\
* 17\end{array}$ & 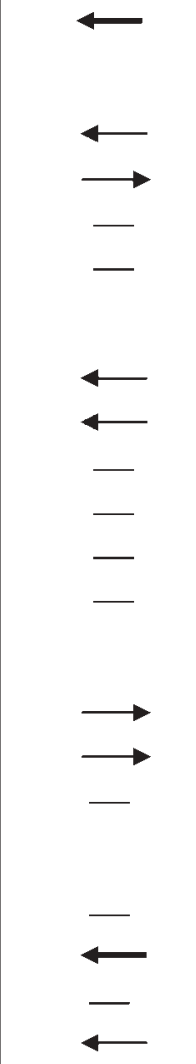 & $* 24$ \\
\hline
\end{tabular}

Fig. 9 Summary rock property trends with increasing sonic velocity (reducing Dt value) and gamma-ray (GR) values. The petrographic data are from Hood et al. (2003).

Note: As sonic velocity increases Dt value (a two way travel time) decreases, large arrow $=\mathrm{R}^{2}=>0.4$, small arrow denotes $\mathrm{R}^{2}=<0.4>0.3$, no trend $=\mathrm{R}^{2}<0.3$. Magnitude of trend $=$ change in Dt or GR with a $25 \%$ change in each rock property/compositional value. ${ }^{*}$ denotes magnitude of change due to size change of $0.25 \mathrm{~mm}$.

\section{Lithology of carbonate-based facies}

Some lithological properties for the four carbonate-based facies A-D (Fig. 7, 10), supported by petrographic and hand specimen information (Hood et al. 2003), are discussed below.

\section{Facies A (calcareous siliciclastite)}

Facies A has a carbonate content of $<25 \%$ and is a siliciclastic-dominated deposit, or siliciclastite. From the general relationships of Dt and GR, these rocks are texturally the finest grained in the Tikorangi Formation and are grey to olive brown, calcareous siliciclastic mudstone and claystone. Traces of very fine sand, glauconite, and skeletal material may occur. Facies A has the lowest bioclast content and the highest matrix and siliciclastic grain contents in the Tikorangi Formation.

\section{Facies B (very calcareous siliciclastite)}

Facies B, defined by carbonate values of 25-50\%, comprises moderately to very calcareous siliciclastic rocks. Texturally this facies is typically coarser than facies A, and is dominated by siltstone and some fine sandstone with reduced matrix and clay contents, and increased amounts of bioclasts. These predominantly siltstone lithologies are generally olive grey, argillaceous, and may contain disseminated carbonaceous material, visible skeletal material, traces of pyrite and glauconite, and scattered very fine quartz and lithic sand grains.

\section{Facies $C$ (muddy limestone)}

Facies $C$ samples have a carbonate content of 50-75\%. They are impure, muddy, light grey to olive grey limestone. Facies $\mathrm{C}$ rocks typically include a variable mix of siliciclastic material, commonly fine quartz and lithic sand, and traces of glauconite and pyrite. Skeletal material dominates these rocks and is generally both fine grained and fragmental. Interparticle spaces are filled by muddy matrix and less common (micro)spar cement.

\section{Facies D (coarse limestone)}

Facies D comprises relatively clean (i.e., less muddy), generally off-white or medium to light grey limestones whose carbonate contents are $>75 \%$. These limestones are dense and highly competent with high bioclast contents. They are commonly associated with increased amounts of spar cement, and typically have low matrix and siliciclastic contents. 


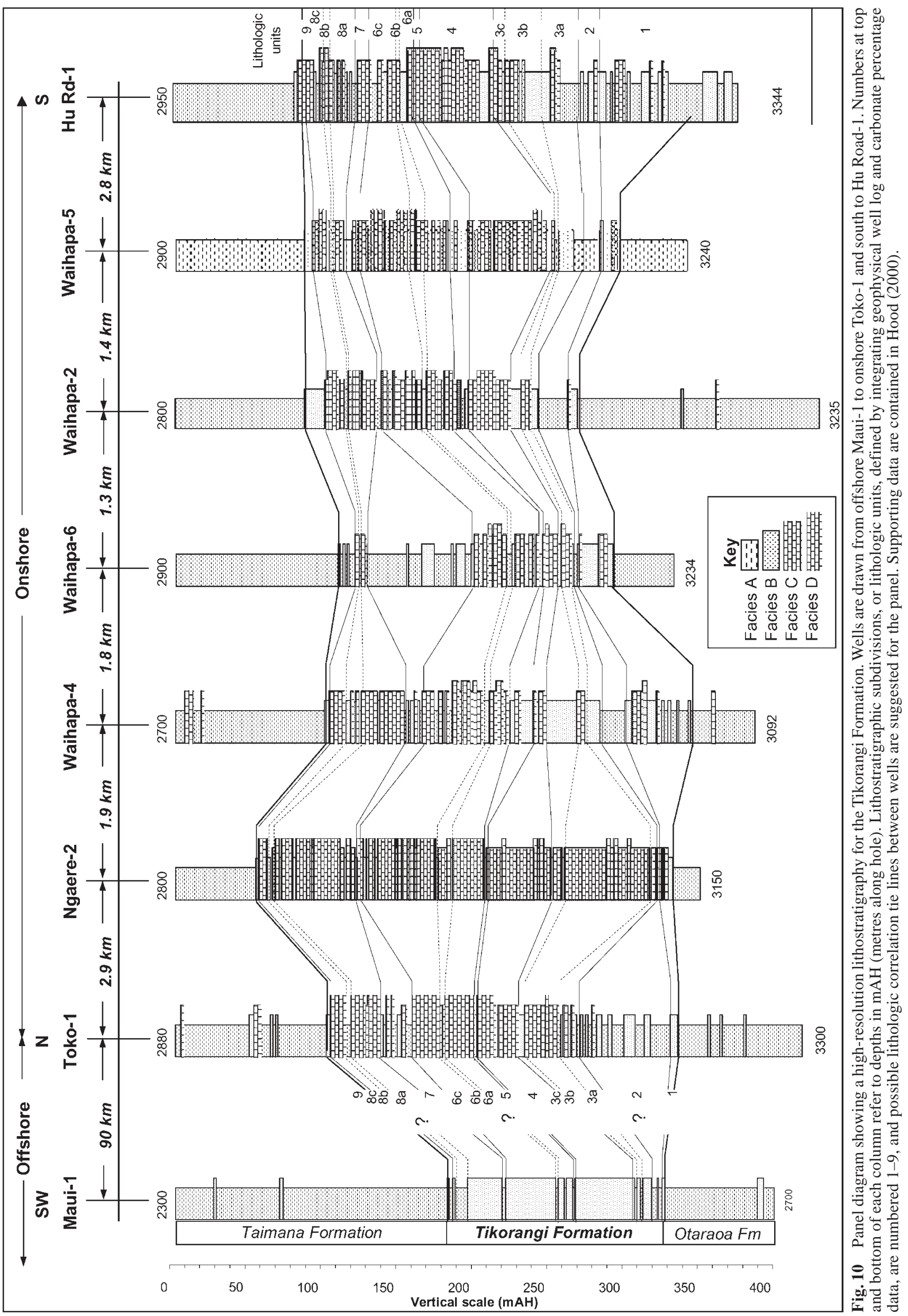




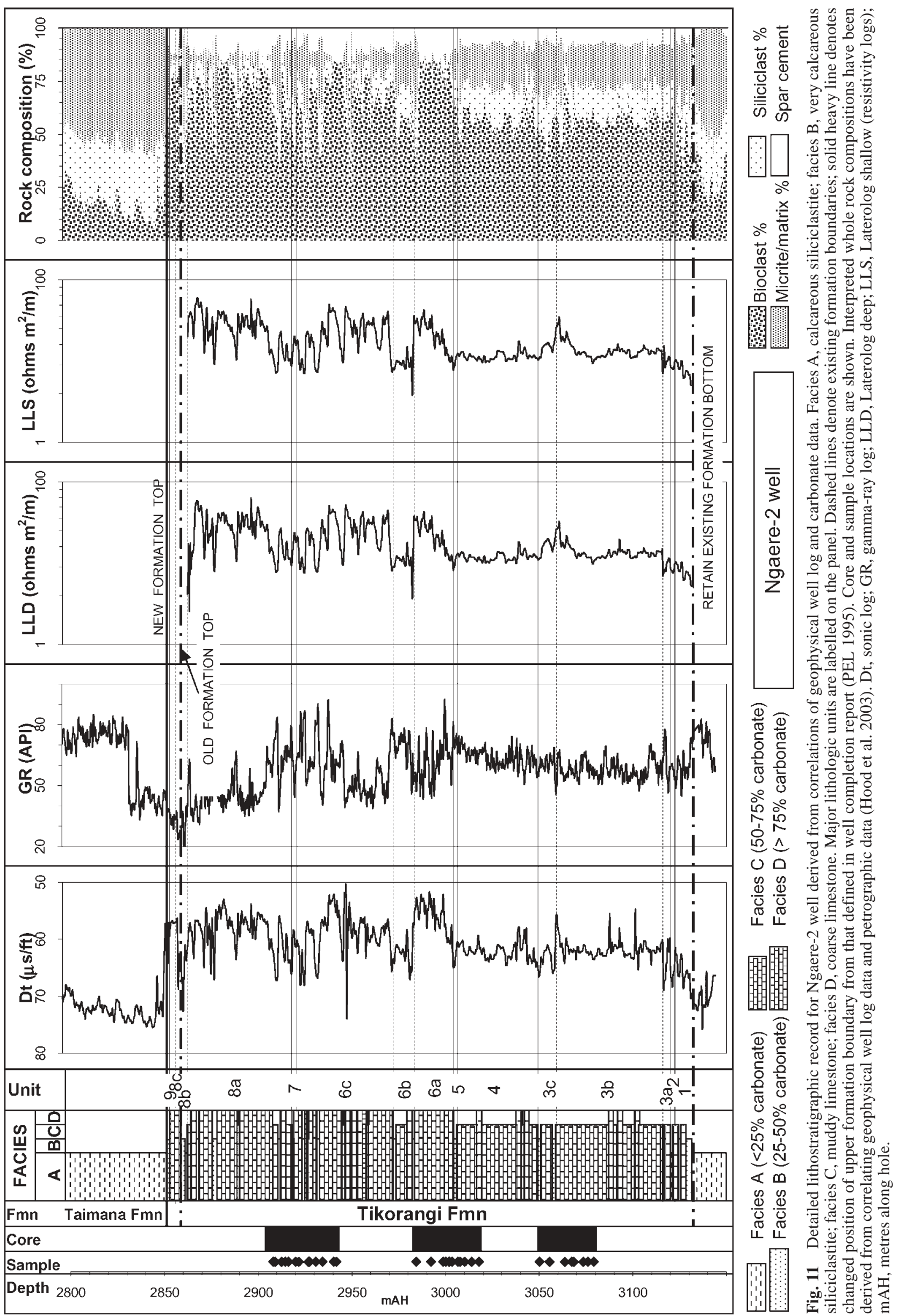




\section{Distribution of carbonate facies}

Table 2 records the abundance distribution of the various carbonate facies in the Tikorangi Formation at each well. Note the dominance of facies B in offshore Maui-1, and the absence of any limestone facies C or D. On the other hand, Ngaere-2 not only contains the thickest Tikorangi Formation of the eight wells studied, but it is the "cleanest" and most limestone rich (Fig. 10). Toko-1, Waihapa-2, -4, and -5, and Hu Road-1 wells contain a more even distribution of both carbonate and siliciclastic rich facies. Waihapa- 6 is the least "limestone-like" of the foredeep megafacies with a high proportion of siliciclastic facies A and B. Based on the distribution of facies in relation to overlying and underlying units, some revised positions for the base and top of the Tikorangi Formation are suggested for the study wells (Table 2). Until now, these boundaries have been defined solely on a change in geophysical log response, rather than on a known change in facies.

\section{General observations}

The basal Tikorangi Formation is commonly carbonate poor and grades from the underlying Otaraoa Formation through siliciclastic-dominated facies A upwards into a sequence of alternating mudstone and siltstone (facies B) before, in most cases, thin limestone intervals (facies C) are encountered (Fig. 10). The base of the Tikorangi Formation is defined lithostratigraphically by an obvious change from facies A dominance, and geophysically by a correlatable marked decrease in Dt and GR values. Upon entering the lower Tikorangi Formation, the overall carbonate content typically increases upwards through impure muddy limestone of facies C (50-75\% carbonate) to coarser limestone of facies D (>75\% carbonate). Some of these limestone units appear to be largely uninterrupted over intervals as thick as $80 \mathrm{~m}$ (Fig. 10). Thinner, less well developed limestone beds are commonly separated by either single siltstone beds or, more commonly in the upper parts of the formation, by either alternating siltstone-mudstone or by solely mudstone facies. In contrast to the lower gradational boundary, the upper contact of Tikorangi Formation with the overlying Taimana Formation is abrupt, and in all cases passes from muddy facies $C$ or purer facies D limestone into thin, very calcareous siliciclastite of facies B. The low-carbonate, siliciclasticdominated facies A then marks the base of the overlying Taimana Formation. Overall, the foredeep sections of the Tikorangi Formation are dominated by limestone facies with generally less common interbeds of siliciclastic-dominated facies that are most conspicuous in the lower part of the formation (Fig. 10).

The basinal Tikorangi Formation in offshore Maui-1 well comprises a much simpler lithologic succession than in the onshore wells because of the total dominance of siliciclasticrich facies A and B (Fig. 10). The foredeep Waihapa-6 well shows some affinities with Maui-1 well by being a more siliciclastic-dominated succession, with no development of the thick limestone occurring in other onshore wells.

Table 2 Distribution of carbonate-based facies A-D in Tikorangi Formation at each studied well. Stratigraphic data compiled from well completion reports for individual wells; note the suggested revised positions of the lower and upper boundaries of the formation. mAH, metres along hole; TVSS, true vertical subsea; TST, true stratigraphic thickness; ${ }^{*}$ denotes well did not reach sufficient depth to confirm base of Tikorangi Formation; TD, total depth reached in well during drilling.

\begin{tabular}{|c|c|c|c|c|c|c|c|c|}
\hline & Maui-1 & Toko-1 & Ngaere-2 & Waihapa-4 & Waihapa-6 & Waihapa-2 & Waihapa-5 & $\mathrm{Hu} \mathrm{Rd}-1$ \\
\hline TIKORANGI FORMATION & & & & & & & & \\
\hline $\begin{array}{l}\text { Existing stratigraphic data } \\
\text { Top (mAH) } \\
\text { Top (mTVSS) } \\
\text { Base (mAH) } \\
\text { Base (mTVSS) } \\
\text { Thickness (mAH) } \\
\text { Thickness (mTST) }\end{array}$ & $\begin{array}{c}2510 \\
? \\
2629 \\
? \\
119 \\
?\end{array}$ & $\begin{array}{c}2929 \\
2772 \\
3227 \\
2941 \\
298 \\
298\end{array}$ & $\begin{array}{c}2861 \\
2611 \\
3133 \\
2836 \\
272 \\
227\end{array}$ & $\begin{array}{c}2794 \\
2567 \\
3051 \\
2823 \\
256 \\
257\end{array}$ & $\begin{array}{c}3012 \\
2781 \\
3202 \\
2968 \\
190 \\
153\end{array}$ & $\begin{array}{c}2902 \\
2655 \\
3094 \\
2846 \\
192 \\
168\end{array}$ & $\begin{array}{c}2994 \\
2743 \\
3194 \\
2943 \\
200 \\
199\end{array}$ & $\begin{array}{c}3035 \\
2782 \\
* 3350 \mathrm{TD} \\
? \\
* 315 \\
?\end{array}$ \\
\hline $\begin{array}{l}\text { Revised stratigraphic data } \\
\text { Top (mAH) } \\
\text { Base (mAH) } \\
\text { Total thickness (mAH) }\end{array}$ & $\begin{array}{c}2482 \\
2627 \\
145\end{array}$ & $\begin{array}{c}2982 \\
3217 \\
235\end{array}$ & $\begin{array}{c}2854 \\
3132 \\
278\end{array}$ & $\begin{array}{c}2802 \\
3050 \\
248\end{array}$ & $\begin{array}{c}3008 \\
3193 \\
185\end{array}$ & $\begin{array}{c}2888 \\
3072 \\
184\end{array}$ & $\begin{array}{c}2986 \\
3196 \\
210\end{array}$ & $\begin{array}{c}3035 \\
3295 \\
260\end{array}$ \\
\hline $\begin{array}{l}\text { FACIES } \\
\text { Facies A } \\
\text { Thickness (mAH) } \\
\% \text { Total thickness } \\
\text { Range thickness (mAH) }\end{array}$ & $\begin{array}{c}28 \\
19 \\
2-8\end{array}$ & $\begin{array}{c}58 \\
25 \\
<2-14\end{array}$ & $\begin{array}{c}6 \\
2 \\
<2\end{array}$ & $\begin{array}{c}53 \\
21 \\
2-20\end{array}$ & $\begin{array}{c}16 \\
9 \\
2-4\end{array}$ & $\begin{array}{c}28 \\
15 \\
<2-20\end{array}$ & $\begin{array}{c}30 \\
14 \\
<2-16\end{array}$ & $\begin{array}{c}51 \\
20 \\
2-14\end{array}$ \\
\hline $\begin{array}{l}\text { Facies B } \\
\text { Thickness (mAH) } \\
\% \text { Total thickness } \\
\text { Range thickness (mAH) }\end{array}$ & $\begin{array}{c}117 \\
81 \\
1-37\end{array}$ & $\begin{array}{c}54 \\
23 \\
<2-8\end{array}$ & $\begin{array}{c}36 \\
13 \\
<2-4\end{array}$ & $\begin{array}{c}79 \\
32 \\
2-22\end{array}$ & $\begin{array}{c}40 \\
22 \\
<2-11\end{array}$ & $\begin{array}{c}55 \\
30 \\
2-14\end{array}$ & $\begin{array}{c}64 \\
30 \\
<2-10\end{array}$ & $\begin{array}{c}63 \\
24 \\
2-18\end{array}$ \\
\hline $\begin{array}{l}\text { Facies C } \\
\text { Thickness (mAH) } \\
\% \text { Total thickness } \\
\text { Range thickness (mAH) }\end{array}$ & $\begin{array}{l}0 \\
0 \\
-\end{array}$ & $\begin{array}{c}54 \\
23 \\
<2-14\end{array}$ & $\begin{array}{c}113 \\
41 \\
<2-28\end{array}$ & $\begin{array}{c}96 \\
39 \\
2-16\end{array}$ & $\begin{array}{c}40 \\
22 \\
<2-6\end{array}$ & $\begin{array}{c}53 \\
29 \\
<2-11\end{array}$ & $\begin{array}{c}88 \\
42 \\
2-14\end{array}$ & $\begin{array}{c}94 \\
36 \\
2-14\end{array}$ \\
\hline $\begin{array}{l}\text { Facies D } \\
\text { Thickness (mAH) } \\
\text { \% Total thickness } \\
\text { Range thickness (mAH) }\end{array}$ & $\begin{array}{l}0 \\
0 \\
-\end{array}$ & $\begin{array}{c}69 \\
29 \\
2-20\end{array}$ & $\begin{array}{c}123 \\
44 \\
<2-21\end{array}$ & $\begin{array}{c}20 \\
8 \\
3-6\end{array}$ & $\begin{array}{c}12 \\
6 \\
<2-5\end{array}$ & $\begin{array}{c}48 \\
26 \\
<2-10\end{array}$ & $\begin{array}{c}28 \\
13 \\
2-9\end{array}$ & $\begin{array}{c}52 \\
20 \\
2-25\end{array}$ \\
\hline
\end{tabular}




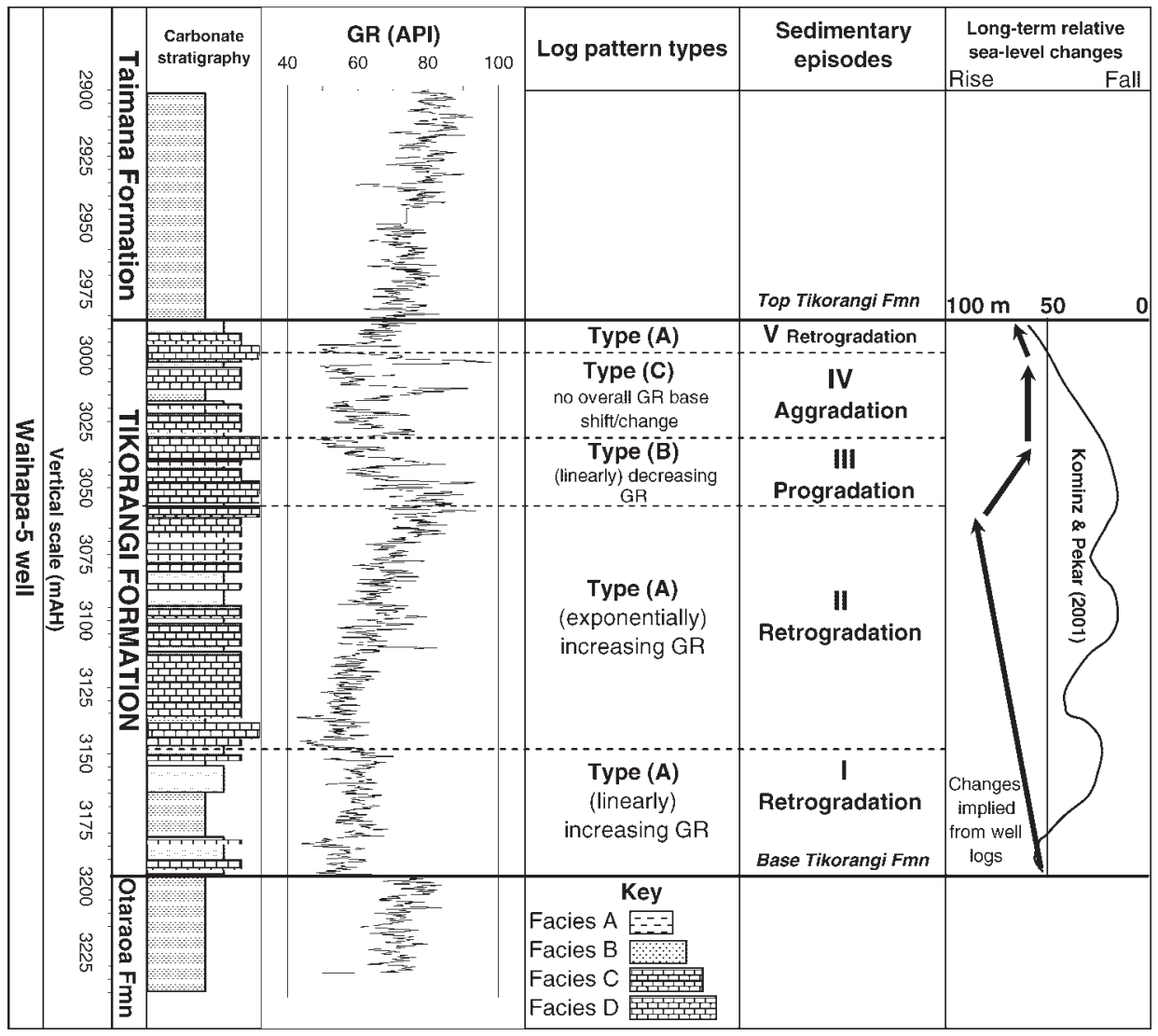

Fig. 12 Major log pattern types (A-C), interpreted sedimentation patterns and associated sedimentary episodes I-V, and inferred relative sea-level changes for the Waihapa-5 GR plot. Note the upward change from a more regular and subdued log response in the lower two-thirds of the Tikorangi Formation to a more erratic, spiky log response in the top third.

\section{Lithostratigraphic units and correlation}

The onshore wells are only $1-3 \mathrm{~km}$ apart. Tie lines have been suggested for facies between the onshore wells, defining nine main lithostratigraphic units (1-9) and several subunits (Fig. 10; Appendix 1). The lithologic units in offshore Maui-1 well mainly comprise only one facies type, whereas most units in the onshore wells include a dominant, or occasionally co-dominant facies, along with sub-dominant and minor facies associations (Table 3).

Any correlation of the onshore well stratigraphy to the single offshore well remains tentative because of uncertainty of the exact age of the Tikorangi Formation in Maui-1 (Fig. 10). The original Maui-1 well completion report (Jonkers et al. 1969) suggested an early Oligocene to earliest Miocene
(Whaingaroan-Waitakian or even younger) age. However, a review of the biostratigraphy of neighbouring Maui-2 well by Scott (1985), which we consider here to be a good surrogate for Maui-1 given its close proximity and similar thickness (Fig. 3), showed the Tikorangi Formation here is mainly late Oligocene in age (Waitakian) with a thin $(16 \mathrm{~m})$ condensed early Oligocene (Duntroonian) section at the base. This suggests that, like the onshore foredeep sections (Fig. 2), the Tikorangi Formation at Maui-1 is perhaps dominantly latest Oligocene (early Waitakian) in age, in which case linking tie lines between onshore and offshore wells should be possible. Significantly, and despite the facies differences, a similar number of lithostratigraphic units can be recognised in offshore Maui-1 well as in the onshore wells (Fig. 10).

Table 3 Summary of the distribution of carbonate facies A-D in the foredeep and basinal megafacies (see Fig. 9).

\begin{tabular}{lccccccccccccccc}
\hline \multicolumn{11}{c}{ Tikorangi Formation stratigraphic units } \\
\hline Foredeep megafacies & 1 & 2 & $3 \mathrm{a}$ & $3 \mathrm{~b}$ & $3 \mathrm{c}$ & 4 & 5 & $6 \mathrm{a}$ & $6 \mathrm{~b}$ & $6 \mathrm{c}$ & 7 & $8 \mathrm{a}$ & $8 \mathrm{~b}$ & $8 \mathrm{c}$ & 9 \\
Onshore & & & & & & & & & & & & & \\
Range thickness (m) & $5-61$ & $2-61$ & $2-26$ & $3-57$ & $3-21$ & $7-54$ & $2-16$ & $8-21$ & $3-16$ & $18-51$ & $2-69$ & $5-55$ & $2-11$ & $3-13$ & $2-14$ \\
Average thickness (m) & 23 & 18 & 11 & 18 & 8 & 31 & 7 & 16 & 6 & 30 & 18 & 22 & 4 & 10 & 6 \\
Dominant facies & $\mathrm{B}$ & $\mathrm{A}$ & $\mathrm{B}$ & $\mathrm{C}$ & $\mathrm{B}$ & $\mathrm{C} / \mathrm{D}$ & $\mathrm{B}$ & $\mathrm{C} / \mathrm{D}$ & $\mathrm{B}$ & $\mathrm{C} / \mathrm{D}$ & $\mathrm{A}$ & $\mathrm{C} / \mathrm{D}$ & $\mathrm{B}$ & $\mathrm{C}$ & $\mathrm{B}$ \\
Subdominant facies & $\mathrm{A} / \mathrm{C}$ & - & - & $\mathrm{D}$ & - & - & - & - & $\mathrm{C} / \mathrm{D}$ & $\mathrm{A}$ & $\mathrm{B} / \mathrm{C}$ & - & $\mathrm{A}$ & $\mathrm{D}$ & - \\
Minor facies & $\mathrm{D}$ & $\mathrm{B} / \mathrm{C}$ & $\mathrm{A} / \mathrm{C} / \mathrm{D}$ & $\mathrm{B}$ & $\mathrm{C}$ & $\mathrm{A} / \mathrm{B}$ & $\mathrm{A} / \mathrm{C}$ & $\mathrm{B}$ & - & $\mathrm{B}$ & $\mathrm{D}$ & $\mathrm{A} / \mathrm{B}$ & $\mathrm{C}$ & - & $\mathrm{A}$ \\
Basinal megafacies & 1 & 2 & $3 \mathrm{a}$ & $3 \mathrm{~b}$ & $3 \mathrm{c}$ & 4 & 5 & $6 \mathrm{a}$ & $6 \mathrm{~b}$ & $6 \mathrm{c}$ & 7 & $8 \mathrm{a}$ & $8 \mathrm{~b}$ & $8 \mathrm{c}$ & 9 \\
Offshore & & & & & & & & & & & & & & & \\
Thickness (m) & 2 & 7 & 7 & 2 & 3 & 38 & 1 & 11 & 2 & 33 & 2 & 23 & 8 & 2 & 4 \\
Dominant facies & $\mathrm{B}$ & $\mathrm{A}$ & $\mathrm{B}$ & $\mathrm{B}$ & $\mathrm{A}$ & $\mathrm{B}$ & $\mathrm{A}$ & $\mathrm{B}$ & $\mathrm{A}$ & $\mathrm{B}$ & $\mathrm{A}$ & $\mathrm{B}$ & $\mathrm{A}$ & $\mathrm{B}$ & $\mathrm{A} / \mathrm{B}$ \\
Minor facies & - & $\mathrm{B}$ & $\mathrm{A}$ & - & - & - & - & $\mathrm{A}$ & - & - & - & - & - & - & - \\
\hline
\end{tabular}




\section{GEOPHYSICAL WELL LOG CHARACTERISATION}

Traditionally, well $\log s$ have been used to facilitate correlation, but their patterns can also provide information relevant to the depositional history and sequence stratigraphy of deposits (e.g., Sarg \& Lehmann 1986; Emery \& Myers 1996; Harris et al. 1999). Vertical log profiles can be used to infer changes in depositional energy and patterns of sedimentary infill. Thus, a decrease in the GR log reflects a decrease in natural radiation levels that is typically related to clay content, and consequently implies an increase in grain size and therefore also of environmental energy levels, to which a relative lowering of sea level may be inferred (Rider 1986; Emery \& Myers 1996). The converse applies for an increasing GR log. Resistivity logs (Rt, either ILD or LLD) typically oppose GR trends because resistivity increases as the clay content decreases.

Cursory examination suggests a broadly similar geophysical well log pattern between the wells in the onshore Waihapa-Ngaere Field (Fig. 6). For example, log responses in the lower part of the formation are comparatively subdued compared to those in the upper portion, which are much more erratic, spiked, and highly variable. Only Waihapa-6 departs from this general trend by showing a log response more typical of the upper section over the entire interval. The broad division into a lower and upper log division (Fig. 6) typically matches initially increasing GR values (decreasing $\mathrm{Dt}$ ) followed in the vicinity of the middle part of the formation by a change to overall decreasing GR values (increasing Dt). Overall GR values are indicative of relatively cleaner (less micrite/clay matrix) lithologies in the north of the Waihapa-Ngaere Field. Dt values suggest slightly more competent (indurated/ cemented) lithologies in the northern wells.

It is possible to assign the GR patterns to one or other of three major patterns, labelled type (A), (B), or (C), and exemplified here by Waihapa-5 (Fig. 12). In type (A) the GR values show an overall increase upwards; in type (B) an overall decrease upwards; and in type $(\mathrm{C})$ there is little change upwards but rather an irregular pattern about a fixed medial line position. Most typically, the up-column changes for the type (A) and (B) trends are long-term linear, but sometimes they exhibit exponential growth or decay trends (e.g., lower portions of Waihapa-5, Toko-1, and Waihapa-4) (Fig. 6).

The well $\log$ patterns of type (A), (B), and (C) are interpreted to correspond to episodes of relative basin-margin retrogradation, progradation, and aggradation, respectively (Sarg \& Lehmann 1986), which in turn allows inferences to be drawn concerning variations in relative sea level (Emery \& Myers 1996). Retrogradational trends [type (A)] are characterised by a general fining- (or "dirtying-") upwards, and imply deepening that occurs when sediment supply is less than the rate of creation of accommodation volume (Mitchum et al. 1993). A type (B) $\log$ trend is usually associated with "cleaning upwards", an increasing grain size (coarsening-up trend), or a progradational sequence due to a gradual decrease in clay/silt content. It occurs when sediment supply exceeds accommodation space (Mitchum et al. 1993), so that facies belts migrate basinward to produce a relative shallowing-upwards or regressional sequence. In type (C), an aggradational trend, sediment supply, and rate of volume creation are roughly balanced, resulting in a vertical stacking of facies belts.

\section{DEPOSITIONAL EPISODES}

Five main well log episodes characterise the Tikorangi Formation (Fig. 12). Based on the data assembled in Tables 4 and 5 , their distribution across the wells is schematically depicted in Fig. 13.

\section{Episode I}

An abrupt change from high to much lower GR values marks the base of the Tikorangi Formation and sedimentary episode I (Fig. 12, 13). Across this surface, depositional conditions changed from relatively low energy, slightly calcareous claystone or mudstone associated with facies A of the underlying upper Otaraoa Formation, to overlying cleaner and coarser grained, moderately to highly calcareous siltstone to fine sandstone of facies B dominating the basal Tikorangi Formation. Episode I typically shows a slight retrogradational trend (Fig. 12, Table 4). Such a finingupwards sequence is probably indicative of increasing water depths, typically reflected by a change from basal more carbonate rich beds of facies B (and/or C) back to facies Adominated deposits. The retrogradation is inferred to be associated with ongoing foredeep subsidence and some landward movement of facies belts.

About $17 \%$ (av. $38 \mathrm{~m}$ ) of the Tikorangi Formation thickness is associated with this mildly retrogradational episode I (Fig. 13), during which units 1 and 2 (Fig. 10) were mainly deposited, while units $3 \mathrm{a}$ and $3 \mathrm{~b}$ also formed at Ngaere-2 and Waihapa-5, respectively, at this time (Table 5). The apparent diachroneity of the upper episode I boundary can be explained by the complex and variable supply of both reworked and redeposited carbonate (Hood et al. 2003) and siliciclastic sediment, and the resulting variability in stratigraphic unit thickness. Trendline analysis shows that episode I produced generally slightly thicker deposits in the southern wells, particularly at Waihapa-5 and Hu Road-1 (Fig. 13). These sites may have been more proximal at this time to siliciclastic source areas compared to the more northern wells. In the two northern wells, Toko-1 and Waihapa-4, the episode I trend is progradational rather than retrogradational (Table 4). Here, there is an upward change from facies A to B and eventually $\mathrm{C}$ (Table 5), indicative of a decreasing siliciclastic supply, probably because these sites were more proximal to carbonate source areas during this time.

\section{Episode II}

Episode II is characterised by generally pronounced retrogradation, and changes from linearly increasing to exponentially increasing GR values, particularly evident in Waihapa-5 (Fig. 12; Table 4). The episode II lower boundary (Table 5) is marked by a change to more carbonate rich facies, typically muddy limestone of facies $\mathrm{C}$, reflecting progressive drowning of siliciclastic source areas. A range of Tikorangi lithologic units was formed during this retrogradational episode (Table 5). Upper unit 1 developed in Waihapa-4, but more commonly units $3 \mathrm{a}, 3 \mathrm{~b}$, and 4 at the Toko- 1 and $\mathrm{Hu}$ Road-1 sites, while progressively farther south, the stratigraphically higher retrogradational units range from units 5 to $6 \mathrm{c}$.

Unlike episode I, episode II is associated with generally thicker sediments in more northern wells (Fig. 13; Table 4). It is the thickest of all five episodes, comprising on average 


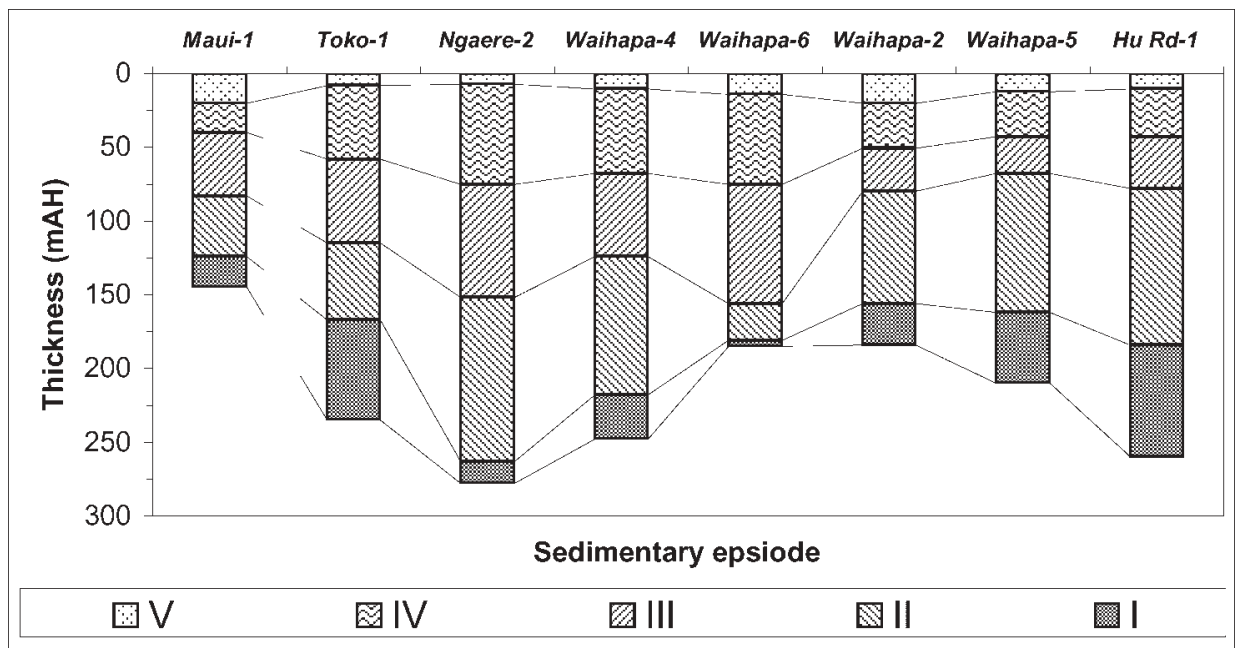

Fig. 13 Distribution of the sedimentary episodes I-V for the Tikorangi Formation across the eight study wells. mAH, metres along hole. Distances between well locations are not to scale.

c. $34 \%$ (or $80 \mathrm{~m}$ ) of the formation thickness. Episode II is particularly long-lived in Ngaere-2, but short-lived in Waihapa-6. The generally more carbonate rich nature of Ngaere-2 suggests a preferential or proximal carbonate supply, whereas Waihapa-6 appears to have occupied an area of low sediment input during this time, possibly as a result of topographic elevation.

The exponential increase of GR values during episode II is suggestive of an accelerating rate of relative sea-level rise (Fig. 12), possibly coincident with rapid deepening of the
Taranaki foredeep trough during this time (King \& Thrasher 1996). Carbonate sedimentation was outpaced by subsidence, and facies belts continued to shift landward. However, shallow carbonate sites continued to shed periodic mass flows during this episode. In Waihapa-5 particularly, a number of small-scale stacked parasequences forming the more general retrogradational trend (Fig. 12) may have resulted from the repetitive filling by mass-emplaced sediments during this rapid submergence episode (e.g., Emery \& Myers 1996).

Table 4 Summary of GR log trends and their sedimentary interpretation for the log episodes I-V in Tikorangi Formation. Type (A), increasing GR upward trend; type (B), decreasing GR upward trend; type (C), no GR base shift; L, linearly increasing or decreasing; E, exponentially increasing or decreasing. prog., progradational trend; retro., retrogradational trend; aggrad., aggradational trend; Sed., sedimentary.

\begin{tabular}{|c|c|c|c|c|c|c|c|}
\hline Log episode & Toko-1 & Ngaere-2 & Waihapa-4 & Waihapa-6 & Waihapa-2 & Waihapa-5 & $\mathrm{Hu}$ Rd-1 \\
\hline \multicolumn{8}{|l|}{ I } \\
\hline Episode length (mAH) & 68 & 15 & 30 & 4 & 28 & 48 & 76 \\
\hline Episode $\%$ of formation & 29 & 5 & 12 & 2 & 15 & 23 & 29 \\
\hline Well log trend type & $(B)_{L}$ & $(\mathrm{~A})_{\mathrm{L}}$ & $(\mathrm{B})_{\mathrm{L}}$ & $(\mathrm{A})_{\mathrm{L}}$ & $(\mathrm{A})_{\mathrm{L}}$ & $(\mathrm{A})_{\mathrm{L}}$ & $(\mathrm{A})_{\mathrm{E}}$ \\
\hline Sed. interpretation & prog. & retro. & prog. & retro. & retro. & retro. & retro. \\
\hline \multicolumn{8}{|l|}{ II } \\
\hline Episode length (mAH) & 52 & 111 & 94 & 25 & 76 & 94 & 106 \\
\hline Episode $\%$ of formation & 22 & 40 & 38 & 14 & 41 & 45 & 41 \\
\hline Well log trend type & $(\mathrm{A})_{\mathrm{E}}$ & $(\mathrm{A})_{\mathrm{E}}$ & $\mathrm{B}_{\mathrm{L}} / \mathrm{A}_{\mathrm{E}}$ & $\mathrm{B}_{\mathrm{E}} / \mathrm{A}_{\mathrm{E}}$ & $\mathrm{B}_{\mathrm{L}} / \mathrm{A}_{\mathrm{L}}$ & $(\mathrm{A})_{\mathrm{E}}$ & $(\mathrm{B})_{\mathrm{L}}$ \\
\hline Sed. interpretation & retro. & retro. & prog./retro. & prog./retro. & prog./retro. & retro. & prog. \\
\hline \multicolumn{8}{|l|}{ III } \\
\hline Episode length (mAH) & 57 & 77 & 56 & 81 & 29 & 25 & 35 \\
\hline Episode $\%$ of formation & 24 & 28 & 23 & 44 & 16 & 12 & 13 \\
\hline Well log trend type & $(\mathrm{B})_{\mathrm{L}} /(\mathrm{C})$ & $(\mathrm{B})_{\mathrm{L}} /(\mathrm{C})$ & $(\mathrm{B})_{\mathrm{L}}$ & $(\mathrm{B})_{\mathrm{E}} /(\mathrm{A})_{\mathrm{E}}$ & $(\mathrm{B})_{\mathrm{L}}$ & $(B)_{L}$ & $(\mathrm{C}) /(\mathrm{B})_{\mathrm{L}}$ \\
\hline Sed. interpretation & prog./aggrad. & prog./aggrad. & prog. & prog./retro. & prog. & prog. & aggrad./prog. \\
\hline \multicolumn{8}{|l|}{ IV } \\
\hline Episode length (mAH) & 50 & 68 & 58 & 61 & 31 & 31 & 33 \\
\hline Episode $\%$ of formation & 21 & 24 & 23 & 33 & 17 & 15 & 13 \\
\hline Well log trend type & $(\mathrm{B})_{\mathrm{L}} /(\mathrm{C})$ & $(\mathrm{B})_{\mathrm{L}} /(\mathrm{C})$ & $(\mathrm{B})_{\mathrm{E}} /(\mathrm{C})$ & $(\mathrm{B})_{\mathrm{L}} /(\mathrm{C})$ & (C) & (C) & $(\mathrm{B})_{\mathrm{L}} /(\mathrm{C})$ \\
\hline Sed. interpretation & prog./aggrad. & prog./aggrad. & prog./aggrad. & prog./aggrad. & aggrad. & aggrad. & prog./aggrad. \\
\hline \multicolumn{8}{|l|}{ V } \\
\hline Episode length (mAH) & 8 & 7 & 10 & 14 & 20 & 12 & 10 \\
\hline Episode $\%$ of formation & 3 & 3 & 4 & 8 & 11 & 6 & 4 \\
\hline Well log trend type & $(\mathrm{A})_{\mathrm{L}}$ & $(\mathrm{A})_{\mathrm{L}}$ & $(\mathrm{A})_{\mathrm{L}}$ & $(A)_{E}$ & $(A)_{E}$ & $(\mathrm{~A})_{\mathrm{L}}$ & $(\mathrm{A})_{\mathrm{L}}$ \\
\hline Sed. interpretation & retro. & retro. & retro. & retro. & retro. & retro. & retro. \\
\hline
\end{tabular}


The only exception to a retrogradational episode II is at Hu Road-1 (Table 4), where instead a thick progradational stack of predominantly limestone occurs. These limestone beds are uncharacteristically coarse and include some very shallow water skeletons (e.g., red algae and larger benthic foraminifera), suggesting they represent a carbonate facies formed on or about topographic highs (pedestals) upon shelf areas. Siliciclastic sediment bypassing and overall carbonate progradation are likely in such proximal shelf sites.

\section{Episode III}

The base of episode III probably marks the maximum flooding surface for the Tikorangi Formation, coincident with a regional change to carbonate-rich facies $\mathrm{C}$ in wells. It is characterised by a relatively short lived progradational episode in Waihapa-5 (Fig. 12), which tends to be more prograding aggradation in the northern wells (Table 4). A feature of episode III here (e.g., at Toko-1 and Ngaere-2; Fig. 6) is the thick, often box-car, crescent, or barrel shape of GR units, suggestive of mass-emplaced deposits (Mitchum et al. 1993). Barrel-type units are particularly prominent in Waihapa-6. This is typical of submarine fan deposition in which sandy parts of the leveed channels have a consistently rounded or crescent-shaped pattern (Emery \& Myers 1996). In the more southern wells (e.g., Waihapa-2 and -5), distinctive mass-emplaced signatures are more difficult to recognise, possibly because they are smaller scale units associated with more distal sites from those areas actively supplying carbonate material at the time.

Episode III shows generally better developed thicker sediments in the northern wells (Fig. 13; Table 4). On average, the episode forms $23 \%$ (or c. $51 \mathrm{~m}$ ) of the total thickness of the Tikorangi Formation. The episode is dominated by unit $6 \mathrm{c}$, which in several wells sees the first appearance of clean, coarse-grained limestone-forming facies D (Table 5).

A decrease in basin subsidence to a rate relatively less than that of sediment influx probably occurred during this episode, so that the foredeep tended to fill. The carbonate system would have tended to prograde during such a decrease in the rate of sea-level rise. In many carbonate settings, such as the Bahaman platform, highstand shedding is responsible for mass transport of shoal-water carbonate sediment into deeper water (e.g., Driscoll et al. 1991; Emery \& Myers 1996; Westphal et al. 1999). A comparable mechanism may have operated locally upon the Tikorangi temperate shelf, notably about upstanding highs, but the tectonic situation was such that oversteepening of depositional slopes about the basin margin, and triggering by seismic and storm events, were probably most effective for initiating mass flows and off-shelf transportation of carbonate sediment (e.g., Foreman et al. 1991).

\section{Episode IV}

Episode IV is typified by aggradation to prograding aggradation, in which no or little overall GR baseline shift

Table 5 Summary data defining the boundary conditions between the five log episodes (I-V) in Tikorangi Formation. b, base; 1, lower; m, middle; u, upper; t, top; /, boundary; A, calcareous siliciclastites (<25\% carbonate); B, very calcareous siliciclastites (25-50\% carbonate); C, muddy limestones (50-75\% carbonate); D, coarse limestones (>75\% carbonate).

\begin{tabular}{|c|c|c|c|c|c|c|c|c|}
\hline $\begin{array}{l}\text { Sedimentary } \\
\text { episode }\end{array}$ & $\begin{array}{l}\text { Episode } \\
\text { boundary }\end{array}$ & Toko-1 & Ngaere-2 & Waihapa-4 & Waihapa-6 & Waihapa-2 & Waihapa-5 & $\mathrm{Hu} \mathrm{Rd}-1$ \\
\hline \multirow{6}{*}{ I } & Lower boundary & & & & & & & \\
\hline & Lithostratigraphic unit & b1 & b1 & b1 & b1 & b1 & b1 & b1 \\
\hline & Carbonate facies & $\mathrm{A} / \mathrm{B}$ & $\mathrm{A} / \mathrm{B}$ & $\mathrm{A} / \mathrm{B}$ & $\mathrm{A} / \mathrm{B}$ & $\mathrm{A} / \mathrm{B}$ & $\mathrm{A} / \mathrm{B}$ & $\mathrm{A} / \mathrm{B}$ \\
\hline & Upper boundary & & & & & & & \\
\hline & Lithostratigraphic unit & $2 / 3 \mathrm{a}$ & $3 b / 3 c$ & $\mathrm{~m} 1$ & $2 / 3 a$ & $2 / 3 \mathrm{a}$ & $3 c / 4$ & $2 / 3 a$ \\
\hline & Carbonate facies & $\mathrm{A} / \mathrm{B}$ & $\mathrm{B} / \mathrm{C}$ & $\mathrm{A} / \mathrm{C}$ & $\mathrm{A} / \mathrm{B}$ & $\mathrm{A} / \mathrm{B}$ & $\mathrm{B} / \mathrm{C}$ & $\mathrm{A} / \mathrm{C}$ \\
\hline \multirow{6}{*}{ II } & Lower boundary & & & & & & & \\
\hline & Lithostratigraphic unit & $2 / 3 a$ & $3 b / 3 c$ & m1 & $2 / 3 a$ & $2 / 3 a$ & $3 c / 4$ & $2 / 3 a$ \\
\hline & Carbonate facies & $\mathrm{A} / \mathrm{B}$ & $\mathrm{B} / \mathrm{C}$ & $\mathrm{A} / \mathrm{C}$ & $\mathrm{A} / \mathrm{B}$ & $\mathrm{A} / \mathrm{B}$ & $\mathrm{B} / \mathrm{C}$ & $\mathrm{A} / \mathrm{C}$ \\
\hline & Upper boundary & & & & & & & \\
\hline & Lithostratigraphic unit & $\mathrm{m} 4$ & $\mathrm{~m} 5$ & $5 / 6 a$ & $6 b / 6 c$ & $6 b / 6 c$ & $6 b / 6 c$ & $4 / 5$ \\
\hline & Carbonate facies & $\mathrm{B} / \mathrm{C}$ & $\mathrm{B} / \mathrm{D}$ & $\mathrm{A} / \mathrm{C}$ & $\mathrm{A} / \mathrm{C}$ & $\mathrm{B} / \mathrm{C}$ & $\mathrm{B} / \mathrm{C}$ & $\mathrm{D} / \mathrm{B}$ \\
\hline \multirow{5}{*}{ III } & $\begin{array}{l}\text { Lower boundary } \\
\text { Lithostratigraphic unit }\end{array}$ & m4 & $\mathrm{m} 5$ & $5 / 6 a$ & $6 b / 6 c$ & $6 b / 6 c$ & $6 b / 6 c$ & $4 / 5$ \\
\hline & Carbonate facies & $\mathrm{B} / \mathrm{C}$ & $\mathrm{B} / \mathrm{D}$ & $\mathrm{A} / \mathrm{C}$ & $\mathrm{A} / \mathrm{C}$ & $\mathrm{B} / \mathrm{C}$ & $\mathrm{B} / \mathrm{C}$ & $\mathrm{D} / \mathrm{B}$ \\
\hline & Upper boundary & & & & & & & \\
\hline & Lithostratigraphic unit & $6 c / 7$ & u6c & $6 \mathrm{c} / 7$ & 17 & $6 \mathrm{c} / 7$ & u6c & $6 c / 7$ \\
\hline & Carbonate facies & $\mathrm{D} / \mathrm{A}$ & $\mathrm{D} / \mathrm{B}$ & $\mathrm{C} / \mathrm{A}$ & $\mathrm{B} / \mathrm{A}$ & $\mathrm{D} / \mathrm{A}$ & $\mathrm{D} / \mathrm{B}$ & $\mathrm{C} / \mathrm{A}$ \\
\hline \multirow{6}{*}{ IV } & Lower boundary & & & & & & & \\
\hline & Lithostratigraphic unit & $6 c / 7$ & u6c & $6 c / 7$ & 17 & $6 c / 7$ & u6c & $6 c / 7$ \\
\hline & Carbonate facies & $\mathrm{D} / \mathrm{A}$ & $\mathrm{D} / \mathrm{B}$ & $\mathrm{C} / \mathrm{A}$ & $\mathrm{C} / \mathrm{B}$ & $\mathrm{D} / \mathrm{A}$ & $\mathrm{D} / \mathrm{B}$ & $\mathrm{C} / \mathrm{A}$ \\
\hline & Upper boundary & & & & & & & \\
\hline & Lithostratigraphic unit & $\mathrm{m} 8 \mathrm{c}$ & $\mathrm{u} 8 \mathrm{~b}$ & $\mathrm{u} 8 \mathrm{~b}$ & $\mathrm{~m} 8 \mathrm{~b}$ & $\mathrm{~m} 8 \mathrm{c}$ & $\mathrm{m} 8 \mathrm{c}$ & $18 \mathrm{c}$ \\
\hline & Carbonate facies & $\mathrm{D}$ & $\mathrm{B}$ & $\mathrm{B}$ & $\mathrm{C}$ & $\mathrm{D}$ & $\mathrm{D}$ & $\mathrm{C}$ \\
\hline \multirow{6}{*}{ V } & Lower boundary & & & & & & & \\
\hline & Lithostratigraphic unit & $\mathrm{m} 8 \mathrm{c}$ & $\mathrm{u} 8 \mathrm{~b}$ & $\mathrm{u} 8 \mathrm{~b}$ & $\mathrm{~m} 8 \mathrm{~b}$ & $\mathrm{~m} 8 \mathrm{c}$ & $\mathrm{m} 8 \mathrm{c}$ & $18 \mathrm{c}$ \\
\hline & Carbonate facies & $\mathrm{D}$ & B & B & $\mathrm{C}$ & $\mathrm{D}$ & $\mathrm{D}$ & $\mathrm{C}$ \\
\hline & Upper boundary & & & & & & & \\
\hline & Lithostratigraphic unit & t9 & $\mathrm{t} 9$ & t9 & t9 & t9 & t9 & t9 \\
\hline & Carbonate facies & $\mathrm{B} / \mathrm{A}$ & $\mathrm{B} / \mathrm{A}$ & $\mathrm{B} / \mathrm{A}$ & $\mathrm{B} / \mathrm{A}$ & $\mathrm{B} / \mathrm{A}$ & $\mathrm{B} / \mathrm{A}$ & $\mathrm{B} / \mathrm{A}$ \\
\hline
\end{tabular}




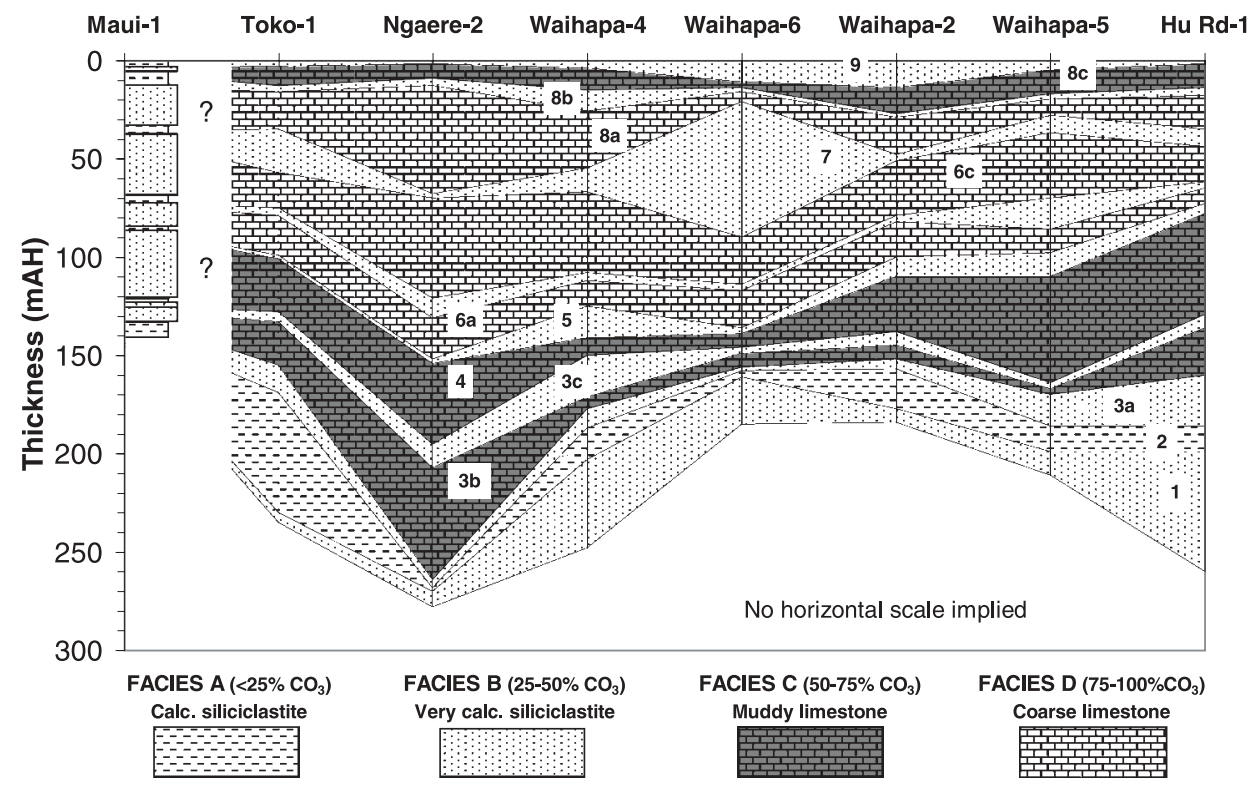

Fig. 14 Summary lithostratigraphic panel diagram for Tikorangi Formation across the study wells showing the correlation of units with top Tikorangi as datum. The dominant carbonate facies (A-D) forming each unit are shown. $\mathrm{mAH}$, metres along hole.

occurs (Table 4). The base of the episode is generally marked by a downgrade in carbonate content from either high carbonate facies $\mathrm{C}$ or D, to typically facies A. This episode marks an increase in availability of siliciclastic material and effectively ends deposition of the carbonate-rich facies $\mathrm{C}$ and $D$ at Waihapa-6. In other wells, only thin periodic influxes of siliciclastic-rich material occurred, with the majority of episode IV dominated by pure limestone of facies D in northern wells, and more muddy limestone of facies $\mathrm{C}$ in southern wells.

During episode IV, the rate of sediment supply and the rate of volume creation were roughly balanced, resulting in vertical stacking of facies belts. This episode, like episodes II and III, produced generally slightly thicker deposits in the northern wells (Fig. 13; Table 4), where box-car or barrelshaped GR patterns are again suggestive of mass emplacement. Mass-emplaced units are not so obvious in the more southern wells and, if present, are thinner and presumably more distal deposits.

The upper boundary of episode IV marks the maximum progradation surface, where GR values are at a minimum. A feature of episode IV is the erratic GR log character in which very high GR peaks may represent sonic spikes corresponding to intervals of background pelagic sedimentation (e.g., Fig. 12). These markers are usually thin, fine-grained, siliciclastic-rich units, or shales, that have high GR response, low resistivity, and low sonic velocity, typical of condensed sedimentary intervals. Episode IV on average forms $21 \%$ (or c. $47 \mathrm{~m}$ ) of the Tikorangi Formation (Fig. 13), and involved deposition of stratigraphic units ranging from uppermost unit $6 \mathrm{c}$ to often mid unit 8 (Table 5).

\section{Episode V}

The base of episode $\mathrm{V}$ occurs in either unit $8 \mathrm{~b}$ or $8 \mathrm{c}$ and represents a short-lived retrogradational phase (Table 4) in which carbonate production from factory sites declined as siliciclastic sedimentation increased with accelerated uplift of source rocks. Continued dilution of the carbonates eventually terminated deposition of the Tikorangi Formation. Episode V is slightly better developed or longer lived in the southern wells, pointing to a more proximal siliciclastic source area in this direction. On average, the episode accounts for only c. $5 \mathrm{~m}$ (or 12\%) of the total thickness of Tikorangi Formation (Fig. 13). It is dominated by units $8 \mathrm{c}$ and 9 (Table 5). The top of episode $\mathrm{V}$ marks the top of unit 9 , in all cases a relatively thin facies B deposit, which changes to facies A once in the overlying Taimana Formation. After this time, only rare thin limestone occurs within the Taimana Formation, ending the previous dominance of carbonate sedimentation.

\section{CONCLUDING REMARKS}

By integrating sample carbonate contents with geophysical log data, a high-resolution carbonate-based lithostratigraphy involving four carbonate facies (A-D) has been established for wells in both the foredeep and basinal megafacies of the Tikorangi Formation (Fig. 10). Siliciclastite of facies A is the least abundant facies, accounting for c. $15 \%$ of the formation in onshore wells, and 20\% in offshore Maui- 1 well. Highly calcareous siltstone to fine sandstone of facies B account for slightly more than one-quarter of the formation onshore and the remaining $80 \%$ of the formation offshore. The two high-carbonate facies, $\mathrm{C}$ and $\mathrm{D}$, represented by muddy fine limestone (50-75\% carbonate) and purer, coarse limestone (>75\% carbonate), respectively, occur solely within the foredeep megafacies in the onshore wells, and together account for c. $60 \%$ of the Tikorangi Formation.

The differing distribution and bedding interrelationships of the four carbonate facies have enabled definition of nine major correlatable lithologic units within the Tikorangi Formation (Fig. 10). These nine units can be simplified by representing each unit by its dominant carbonate facies type (A-D) to produce a summary graphic log for each well (Fig. 14), which in turn forms a basis for developing concept lithostratigraphic sections for the foredeep to offshore basinal megafacies of the Tikorangi Formation (Fig. 15). The basal Tikorangi Formation is unequivocally marked by an increase in carbonate content and appearance of the first moderately calcareous unit comprising facies B. But overall the lower 

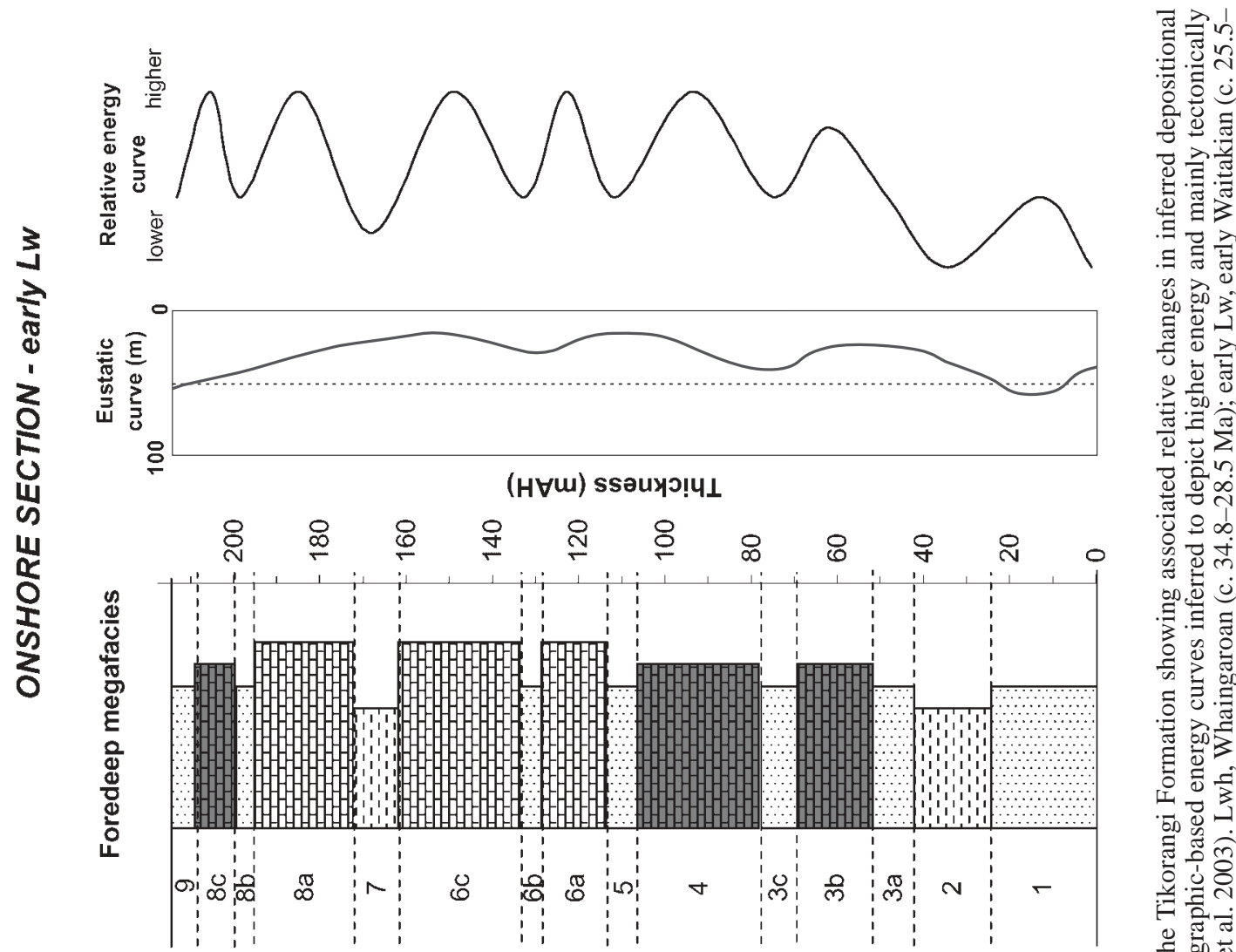

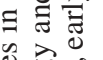

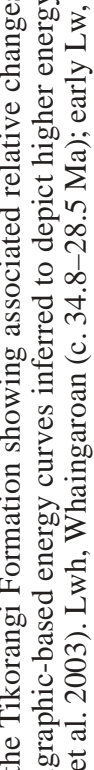

$\stackrel{5}{=}$

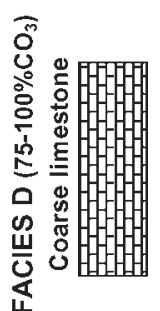

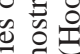

莺 :
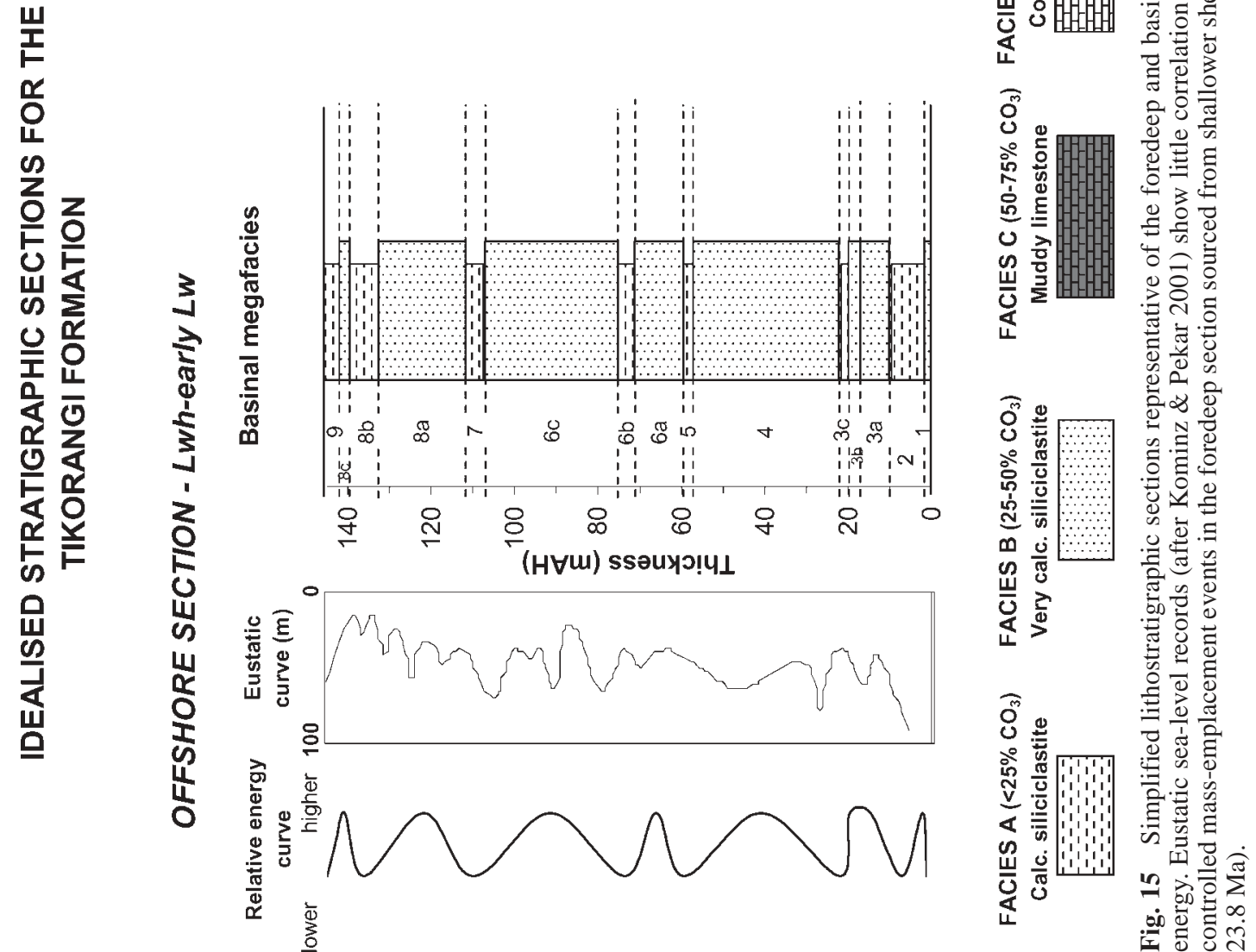


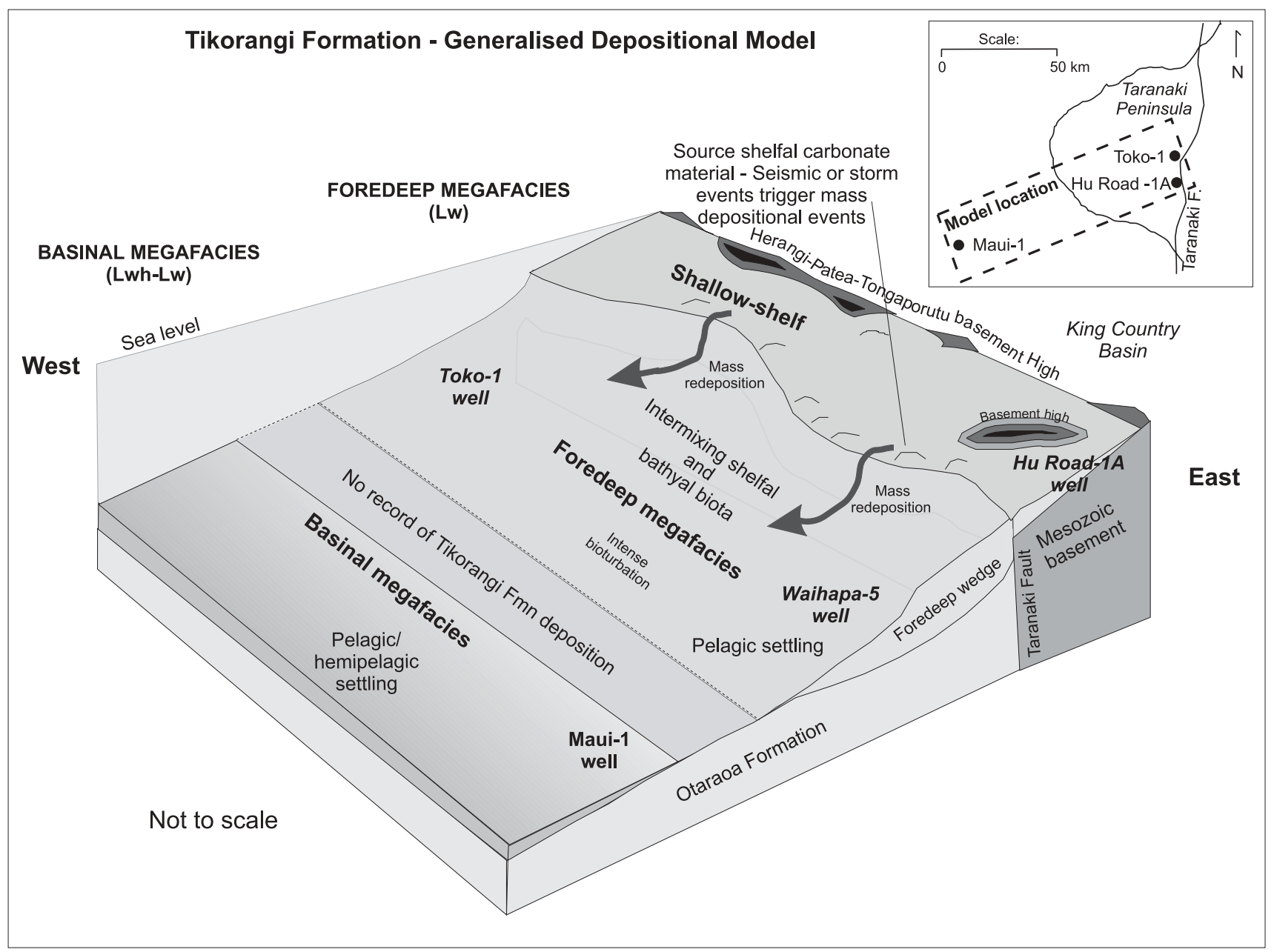

Fig. 16 Generalised Tikorangi Formation depositional model for the central eastern margin of Taranaki Basin to Taranaki Peninsula region (see Fig. 1) showing the location of the two identified megafacies during latest Oligocene (early Lw) time. Lwh = Whaingaroan; $\mathrm{Lw}=$ Waitakian. Region of no Tikorangi carbonate deposition is based on information contained in Palmer (1985), Simpson (1992), King \& Thrasher (1996), and Mauri et al. (1999).

part of the formation is typically carbonate poor and includes an interval of facies A calcareous siliciclastite (unit 2) before passing up into more carbonate rich facies.

The onshore foredeep column emphasises the predominance of muddy and coarse limestone of facies $\mathrm{C}$ and $\mathrm{D}$, respectively. Six major limestone units are identified which are particularly well developed in the middle and upper portions of the formation. These limestone beds are separated by generally thinner, moderately to highly calcareous siliciclastite of facies $\mathrm{B}$, which tend to decrease in thickness upwards as the overall carbonate content increases. In all cases, these interbedded facies B units are $<8 \mathrm{~m}$ thick, while the limestone units are at least twice, and commonly three times, this thickness.

Figure 16 shows a generalised depositional model for the foredeep and basinal end-member megafacies of the Tikorangi Formation during the latest Oligocene. The inset shows the approximate paleogeographic location within the onshore/offshore Taranaki Peninsula region during this time. Of particular importance are the different modes of sediment accumulation shown: (hemi)pelagic in the basinal setting and mixed (hemi)pelagic plus mass redeposition in the foredeep setting. A shallow shelfal region overlying the upthrust
Mesozoic basement high, including isolated basement pedestals, immediately to the west of the Taranaki Fault is inferred to be the source region for redeposited shelfal material occurring in the foredeep. This includes calcareous red algae and large benthic foraminifera (Amphistegina) that are intermixed with planktic foraminifera and nannofossils (coccoliths) (Hood et al. 2003). The ability to address in any detail the most likely mass depositional mechanisms responsible for the displacement of shallow-water biota is limited. This results from a paucity of obvious bedding features in the core material, largely a result of strong sediment bioturbation. The occurrence of occasional Planolites-Chondrites-Zoophycos trace fossil assemblages in foredeep cores is consistent with redeposition into bathyal depths (e.g., Ekdale et al. 1984; Nelson 1985). This topic is addressed in more detail by Hood et al. (2003).

The redeposited nature of the foredeep limestone units suggests that they were associated with higher depositional energies than the finer interbedded siliciclastic-rich units of probable predominantly pelagic/hemipelagic origin. To this end, long-term, fluctuating relative energy curves have been suggested for the offshore and onshore sections in Fig. 15. To ascertain any potential eustatic sea-level control on these 
energy curves, we reproduce the $\delta^{18} \mathrm{O}$-based eustatic curve of Kominz \& Pekar (2001) for the equivalent of the early Waitakian, and Whaingaroan to early Waitakian portions of their Oligocene record against the Tikorangi Formation foredeep and basinal megafacies sections, respectively (Fig. 15). This eustatic curve, based on a suite of boreholes in the New Jersey coastal plain, records for the early Waitakian age interval three main sea-level cycles having a periodicity of c. $0.5 \mathrm{~m}$.y. and decreasing in magnitude upwards from c. 25 to $10 \mathrm{~m}$. Transgressive and highstand sea-level conditions have been implicated in controlling redeposition from carbonate platforms (e.g., Foreman et al. 1991) due to overproduction in shallow water resulting in overloading and steepening of the slope and instability leading to failure and the generation of sediment gravity flows (Tucker \& Wright 1990). The eustatic sea-level records in Fig. 15 lack a sufficient number of cycles, particularly in the foredeep section, to match eustatic sea-level cycles or highstands with carbonate redepositional events. It appears that any influence from eustatic sea-level change was of secondary importance to higher frequency local tectonic events which provided accommodation space, sediment supply, and timing/seismic triggering of high-energy mass-depositional events.

In the basinal section, despite the apparently greater number of eustatic sea-level cycles for the longer Whaingaroan to early Waitakian age range, and consequently the greater potential for event matching, the predominantly early Waitakian age of the Tikorangi Formation offshore (Scott 1985) likely precludes any such correlation.

The summary model for the offshore basinal megafacies (Fig. 15) similarly depicts nine major identifiable units, which in some cases could be lateral correlatives of those onshore (Fig. 10). True limestone beds are absent here and are replaced by moderately to highly calcareous siliciclastite (mudstone) of facies B, with thin interbeds of slightly to moderately calcareous siliciclastite (facies A). The absence of limestone facies $\mathrm{C}$ and $\mathrm{D}$ in Maui-1 points to a depositional site sufficiently distal from any shelf source area that coarse skeletal carbonate material has not been redeposited en masse to this locality. Meanwhile, siliciclastic input has remained sufficiently high to dilute any carbonate accumulating from the pelagic settling of dominantly planktic foraminifera and coccoliths. The calcareous mudstone of Maui-1 (Fig. 16) therefore represents a transition between the foredeep megafacies represented in the onshore wells and a true basinal carbonate ooze which may be found in the more distal western and northwestern extents of the basin (Simpson 1992), far from the influence of any significant siliciclastic input (e.g., Fig. 3).

The current type section for the Tikorangi Formation is in Mangahewa-1 well (van Rijen \& van der Abeele 1963; Palmer 1985). However, it is an unsatisfactory type section because it lacks core material, the general lithologic descriptions for the well coming from ditch-cutting samples taken every $3 \mathrm{~m}$. We instead formally designate Waihapa-5 well (Young \& Carter 1989) as a new reference section for the foredeep megafacies of the Tikorangi Formation because of its representative lithostratigraphy (Fig. 12) and the availability of $>112 \mathrm{~m}$ of core material held in the Ministry of Economic Development's Core Library, Gracefield, Lower Hutt. The formation top, revised here at $2986 \mathrm{mAH}$, and formation base, at $3196 \mathrm{mAH}$, define a $210 \mathrm{~m}$ mixed siliciclastic-carbonate sequence of which $54 \%$ of the formation length is available in conventional core material.
We similarly designate Maui-1 well as a reference section for the basinal megafacies of the Tikorangi Formation for which c. $9 \mathrm{~m}$ of conventional core is available at Gracefield, the only well of this megafacies to provide core material. The revised formation top is at $2482 \mathrm{mAH}$ and base at 2627 $\mathrm{mAH}$, giving a total revised thickness of $145 \mathrm{mAH}$.

Wells in different parts of the Waihapa-Ngaere Field show many similarities, but also differences in geophysical log character (Fig. 6). We suggest the variabilities relate to sites receiving different quantities of both carbonate and siliciclastic material, and are suggestive of inter-facies mixing during sediment reworking and redeposition (Fig. 16). Consequently, some wells (Ngaere-2) are more carbonate rich, while others (Waihapa-6) are more siliciclastic rich. The barrel- and block-shaped signatures of the GR logs in the thick (up to $20 \mathrm{~m}$ or more) limestone-dominated facies, in northern wells in particular, are supportive of considerable mass emplacement of carbonate sediment, which suggests that more proximal carbonate sources lay to the north. The petrogenesis and depositional settings of the Tikorangi Formation deposits are elaborated upon elsewhere by Hood et al. (2003).

Five main correlatable geophysical log patterns have been identified, representative of major depositional episodes within the Tikorangi Formation (Fig. 12, 13). Episode I is characterised by initiation of foredeep subsidence and sediment retrogradation. Episode II continues the episode I retrogradational trend, but with accelerated foredeep subsidence and sea-level rise. Together, episodes I and II may correspond to a long-lived transgressive systems tract, bounded below by a sequence boundary at the base of the Tikorangi Formation, and above by a maximum flooding surface. More generally, these lower two episodes show rather subdued log responses compared to later phases, after which a major change in depositional mechanisms is likely. Episode III shows a progradational trend associated with declining subsidence rates and the movement of carbonate facies basinward. Episode IV is a prograding aggradational sequence dominated, like episode III, by often thick, periodically mass-emplaced carbonate-rich units separated by thin, shale-like units representing sonic spikes of background siliciclastic sedimentation. Episode V marks a return to retrogradational conditions and the reintroduction of siliciclastic material following uplift of basement associated with the propagation of the Australian-Pacific plate boundary through New Zealand. Episodes III-V may represent highstand conditions associated more generally with New Zealand-wide carbonate formation at this time (Nelson 1978a).

Tikorangi Formation sedimentation ended when basement thrusting and uplift of siliciclastic sources along the eastern margin of Taranaki Basin (Fig. 16) in the early Miocene effectively diluted and eventually suppressed carbonate production. This reversed the previous long-term trangressive phase of sedimentation to a major regressive one, which has continued throughout the Neogene to the present day (King \& Thrasher 1996; Kamp et al. 2002).

\section{ACKNOWLEDGMENTS}

This paper derives from a PhD project and post-doctoral research made possible through funding by a University of Waikato Postgraduate Scholarship and funding from the Foundation for Research Science and Technology (UOW815). We thank Petrocorp 
Exploration Ltd (now Shell) for providing access to drill core and in-house petroleum reports, and Ministry of Economic Development staff for assistance in their library and core store facilities in Wellington. We are grateful to John Collen (Victoria University of Wellington) for providing helpful comments on a manuscript version of this paper. Brian Ricketts (University of Waikato) also kindly reviewed an early draft of the manuscript. Julie Palmer (Massey University) and Toni Simo (University of Wisconsin-Madison) are thanked for their insightful comments on the submitted manuscript. We thank Rob Lynch for his editorial guidance in the preparation of this paper.

\section{REFERENCES}

Adams, E. A.; Palmer, J.; Patchett, J. 1980: Toko-1 well completion report. Petroleum Corporation of New Zealand (Exploration) Ltd. Unpublished open-file petroleum report PR761. Wellington, Ministry of Commerce.

Berggren, W. A.; Kent, D. V.; Swisher, C. C.; Aubry, M. P. 1995: A revised Cenozoic geochronology and chronostratigraphy. In: Berggren, W. A.; Kent, D. V.; Aubry, M. P.; Hardenbol, J. ed. Geochronology, time-scales and global stratigraphic correlation. SEPM Special Publication 54: 129-212.

Carter, M.; Kelly, C. 1989a: Waihapa-4 well completion report. Petroleum Corporation of New Zealand (Exploration) Ltd. Unpublished open-file petroleum report PR1852. Wellington, Ministry of Commerce.

Carter, M.; Kelly, C. 1989b: Waihapa-6/Waihapa-6A well completion report. Petroleum Corporation of New Zealand (Exploration) Ltd. Unpublished open-file petroleum report PR1819. Wellington, Ministry of Commerce.

Carter, M.; Rainey, S.; Webby, D.; Kelly, C. 1988: Waihapa-2 well completion report. Petroleum Corporation of New Zealand (Exploration) Ltd. Unpublished open-file petroleum report PR1847. Wellington, Ministry of Commerce.

Driscoll, N. W.; Weisiel, J. K.; Karner, G. D. 1991: Stratigraphic response of a platform to relative sea level changes: Broken Ridge, southeast Indian Ocean. American Association of Petroleum Geologists Bulletin 65: 808-831.

Ekdale, A. A.; Bromley, R. G.; Pemberton, S. G. 1984: Ichnology: the use of trace fossils in sedimentology and stratigraphy. SEPM Short Course No. 15. 317 p.

Emery, D.; Myers, K. 1996: Sequence stratigraphy. Cambridge, Blackwell Science Publishing. 297 p.

Foreman, J. L.; Walker, K. R.; Weber, L. J.; Driese, S. G.; Dreier, R. B. 1991: Slope and basinal carbonate deposition in the Nolichucky shale (Upper Cambrian), east Tennessee: effect of carbonate suppression by siliciclastic deposition on basin-margin morphology. In: Lomando, A. J.; Harris, P. M. ed. Mixed carbonate-siliciclastic sequences. SEPM Core Workshop Notes 15: 511-540.

Harris, P. M.; Saller, A. H.; Simo, J. A. 1999: Introduction. In: Harris, P. M.; Saller, A. H.; Simo, J. A. T. ed. Advances in carbonate sequence stratigraphy: application to reservoirs, outcrops, and models. SEPM Special Publication 63: $1-10$.

Holt, W. E.; Stern, T. A. 1994: Subduction, platform subsidence, and foreland thrust loading: the later Tertiary development of Taranaki Basin, New Zealand. Tectonics 13: 1068-1092.

Hood, S. D. 2000: Subsurface stratigraphy and petrology of a coolwater carbonate fracture reservoir-the mid-Tertiary Tikorangi Formation, Taranaki Basin, New Zealand Unpublished $\mathrm{PhD}$ thesis, lodged in the Library, University of Waikato, Hamilton, New Zealand.

Hood, S. D.; Nelson, C. S.; Kamp, P. J. J. 2001: Diagenetic evolution of the Tikorangi Formation, Waihapa-Ngaere Field, Taranaki Basin: a cool-water carbonate fracture reservoir. In: 2001 Geological Society of New Zealand Annual Conference, Hamilton. Geological Society of New Zealand
Miscellaneous Publication 110A: 69.

Hood, S. D.; Nelson, C. S.; Kamp, P. J. J. 2002: Petrogenesis of the Tikorangi Formation fracture reservoir, Waihapa-Ngaere Field, Taranaki Basin. In: 2002 New Zealand Petroleum Conference Proceedings. Wellington, Ministry of Economic Development. Pp. 206-220.

Hood, S. D.; Nelson, C. S.; Kamp, P. J. J. 2003: Petrogenesis of diachronous mixed carbonate-siliciclastic megafacies in the cool-water Oligocene Tikorangi Formation, Taranaki Basin, New Zealand. New Zealand Journal of Geology and Geophysics 46: 387-405 (this issue).

Jonkers, E. W.; Couper, R. A.; Stainton, P. W. 1969: Well resumé Maui-1. Taranaki offshore concession No. 682. Unpublished open-file petroleum report PR540. Wellington, Ministry of Commerce.

Kamp, P. J. J.; Vonk, A. J.; Bland, K. J.; Griffin, A. G.; Hayton, S.; Hendy, A. J. W.; McIntyre, A. P.; Nelson, C. S.; Naish, T. 2002: Megasequence architecture of Taranaki, Wanganui, and King Country basins and Neogene progradation of two continental margin wedges across western New Zealand. In: 2002 New Zealand Petroleum Conference Proceedings. Wellington, Ministry of Economic Development. Pp. 464-481.

King, P. R. 1988a: Well summary sheets, onshore Taranaki. New Zealand Geological Survey Report G125. Wellington, Department of Scientific and Industrial Research.

King, P. R. 1988b: Well summary sheets, onshore Taranaki. New Zealand Geological Survey Report G127. Wellington, Department of Scientific and Industrial Research.

King, P. R. 1990: Polyphase evolution of the Taranaki Basin, New Zealand: changes in sedimentary and structural style. In: 1989 New Zealand Oil Exploration Conference Proceedings. Wellington, Ministry of Commerce. Pp. 134-150.

King, P. R. 1994: The habitat of oil and gas in Taranaki Basin. In: 1994 New Zealand Petroleum Conference Proceedings. Wellington, Ministry of Commerce. Pp. 180-203.

King, P. R.; Thrasher, G. P. 1992: Post-Eocene development of the Taranaki Basin, New Zealand: convergent overprint of a passive margin. In: Watkins, J. S.; Zhiqiang, F.; McMillen, K. J. ed. Geology and geophysics of continental margins. American Association of Petroleum Geologists Memoir 53: 93-118.

King, P. R.; Thrasher, G. P. 1996: Cretaceous-Cenozoic geology and petroleum systems of the Taranaki Basin, New Zealand. Institute of Geological \& Nuclear Sciences Monograph 13. Lower Hutt, Institute of Geological \& Nuclear Sciences. $243 \mathrm{p}$.

Kominz, M. A.; Pekar, S. F. 2001: Oligocene eustasy from twodimensional sequence stratigraphic backstripping. Geological Society of America Bulletin 113: 291-304.

Leask, W. L. 1980: Basin analysis of Tertiary strata in Golden Bay, Nelson. Unpublished MSc thesis, lodged in the Library, Victoria University of Wellington, Wellington, New Zealand.

McQuillan, H. 1985: Fracture-controlled production from the Oligo-Miocene Asmari Formation in Gachsaran and Bibi Hakimeh Fields, southwest Iran. In: Roehl, P. O.; Choquette, P. W. ed. Carbonate petroleum reservoirs. New York, Springer-Verlag. Pp. 511-524.

Mauri, S.; Brewster, A.; de Bock, F. 1999: PEP38455 Technical report-March 1999. Fletcher Challenge Energy. Unpublished open-file petroleum report PR 2281. Wellington, Ministry of Economic Development.

Ministry of Commerce 2001: New Zealand Petroleum News 36. Wellington. http://www.med.govt.nz/crown_minerals/ 
petroleum/publications/nzpnews/2001.

Mitchum, R. M.; Sangria, J. B.; Vail, P. R.; Wormed, W. W. 1993: Recognising sequences and systems tracts from well logs, seismic data, and biostratigraphy: examples from the Late Cenozoic. In: Weimer, P.; Posamentier, H. W. ed Siliciclastic sequence stratigraphy. Recent developments and applications. American Association of Petroleum Geologists Memoir 58: 163-198.

Morgans, H. E. G. 1985: Biostratigraphy of Waihapa-1 onshore exploration well, Taranaki. New Zealand Geological Survey Report PAL 102. Lower Hutt, Department of Scientific and Industrial Research.

Nelson, C. S. 1973: Stratigraphy and sedimentology of the Te Kuiti Group in Waitomo County, South Auckland. Unpublished $\mathrm{PhD}$ thesis, lodged in the Library, University of Auckland, Auckland, New Zealand.

Nelson, C. S. 1978a: Temperate shelf carbonate sediments in the Cenozoic of New Zealand. Sedimentology 25: 737-771.

Nelson, C. S. 1978b: Stratigraphy and paleontology of the Oligocene Te Kuiti Group, Waitomo County, South Auckland, New Zealand. New Zealand Journal of Geology and Geophysics 21: 553-594.

Nelson, C. S 1985: Bioturbation in middle bathyal, Cenozoic nannofossil oozes and chalks, southwest Pacific. Initial Reports of the Deep Sea Drilling Project 90: 1189-1200.

Nelson, C. S. 1988: An introductory perspective on non-tropical shelf carbonates. Sedimentary Geology 60: 3-12.

Nelson, C. S.; Cooke, P. J. 2001: History of oceanic front development in the New Zealand sector of the Southern Ocean during the Cenozoic: a synthesis. New Zealand Journal of Geology and Geophysics 44: 535-553.

Nelson, C. S.; Hume, T. M. 1987: Paleoenvironmental controls on mineral assemblages in a shelf sequence: Te Kuiti Group, South Auckland, New Zealand. New Zealand Journal of Geology and Geophysics 30: 343-362.

Nelson, C. S.; Kamp, P. J. J.; Young, H. R. 1994: Sedimentology and petrography of mass-emplaced limestone (Orahiri Limestone) on a Late Oligocene shelf, western North Island, and tectonic implications for eastern margin development of the Taranaki Basin. New Zealand Journal of Geology and Geophysics 37: 269-285.

Nelson, C. S.; Lee, D.; Maxwell, P.; Maas, R.; Kamp, P. J. J.; Cooke, S. 2001: Strontium isotope dating of the New Zealand Oligocene: some preliminary results. Geological Society of New Zealand Miscellaneous Publication 110A: 111.

New Zealand Oil \& Gas Ltd 1992: Hu Road 1 \& Hu Road-1A well completion report. Unpublished open-file petroleum report PR1825. Wellington, Ministry of Commerce.

North, F. K. 1985: Petroleum geology. Boston, Allen \& Unwin. $607 \mathrm{p}$.

Palmer, J. A. 1985: Pre-Miocene lithostratigraphy of Taranaki Basin, New Zealand. New Zealand Journal of Geology and
Geophysics 28: 197-216.

Palmer, J. A.; Andrews, P. B. 1993: Cretaceous-Tertiary sedimentation and implied tectonic controls on the structural evolution of Taranaki Basin, New Zealand. In: Ballance, P. F. $e d$. South Pacific sedimentary basins. Sedimentary basins of the world 2. Amsterdam, Elsevier. Pp. 309-328.

Petrocorp Exploration Limited 1995: Ngaere-2 well completion report. Unpublished open-file petroleum report PR1956. Wellington, Ministry of Commerce.

Pilaar, W. F. H.; Wakefield, L. L. 1978: Structural and stratigraphic evolution of the Taranaki Basin, offshore North Island, New Zealand. The APEA Journal 18: 93-101.

Rider, M. H. 1986: The geological interpretations of well logs. Glasgow, Blackie. 168 p.

Sarg, J. F.; Lehmann, P. J. 1986: Lower and middle Guadalupian facies and stratigraphy, San Andres-Grayburg Formations, Permian basin, Guadalupe Mountains, New Mexico. In: Moore, G. E.; Wilde, G. L. ed. Lower and middle Guadalupian facies, stratigraphy, and reservoir geometries, San Andres-Grayburg Formations, Guadalupe Mountains, New Mexico and Texas: Midland, Permian Basin Section. SEPM Special Publication 86-25: 1-36.

Scoffin, T. P. 1987: An introduction to carbonate sediments and rocks. London, Blackie and Son. 274 p.

Scott, G. H: 1985: Biostratigraphic revision of Maui-2 offshore well south Taranaki Basin. New Zealand Geological Survey Report PAL 111. Lower Hutt, Department of Scientific and Industrial Research.

Simpson, J. 1992: Taranaki Basin review. Technical evaluation of the Tikorangi Limestone. New Plymouth, Petrocorp Exploration Ltd.

Stern, T. A.; Davey, F. J. 1990: Deep seismic expression of a foreland basin: Taranaki Basin, New Zealand. Geology 18: 979-982.

Stern, T. A.; Holt, W. E. 1994: Platform subsidence behind an active subduction zone. Nature 368: 233-236.

Tucker, M. E.; Wright, V. P. 1990: Carbonate sedimentology. Oxford, Blackwell Scientific Publications. 482 p.

van Rijen, W. M.; van der Abeele, D. 1963: Exploration well résumé Mangahewa-1. Shell BP and Todd Oil Services Ltd. New Zealand unpublished open-file petroleum report PR428. Wellington, Ministry of Commerce.

Westphal, H.; Reijmer, J. J. G.; Head, M. J. 1999: Sedimentary input and diagenesis on a carbonate slope (Bahamas): response to morphologic evolution of the carbonate platform and sea-level fluctuations. In: Harris, P. M.; Saller, A. H.; Simo, J. A. T. ed. Advances in carbonate sequence stratigraphy: application to reservoirs, outcrops, and models. SEPM Special Publication 63: 247-275.

Young, J.; Carter, M. 1989: Waihapa-5 well completion report. Petroleum Corporation of New Zealand (Exploration) Ltd. Unpublished open-file petroleum report PR1851. Wellington, Ministry of Commerce. 
APPENDIX 1 Hierarchical lithological flowchart for the Tikorangi Formation showing the interrelationships amongst the various kinds of "facies" which underpin this study.

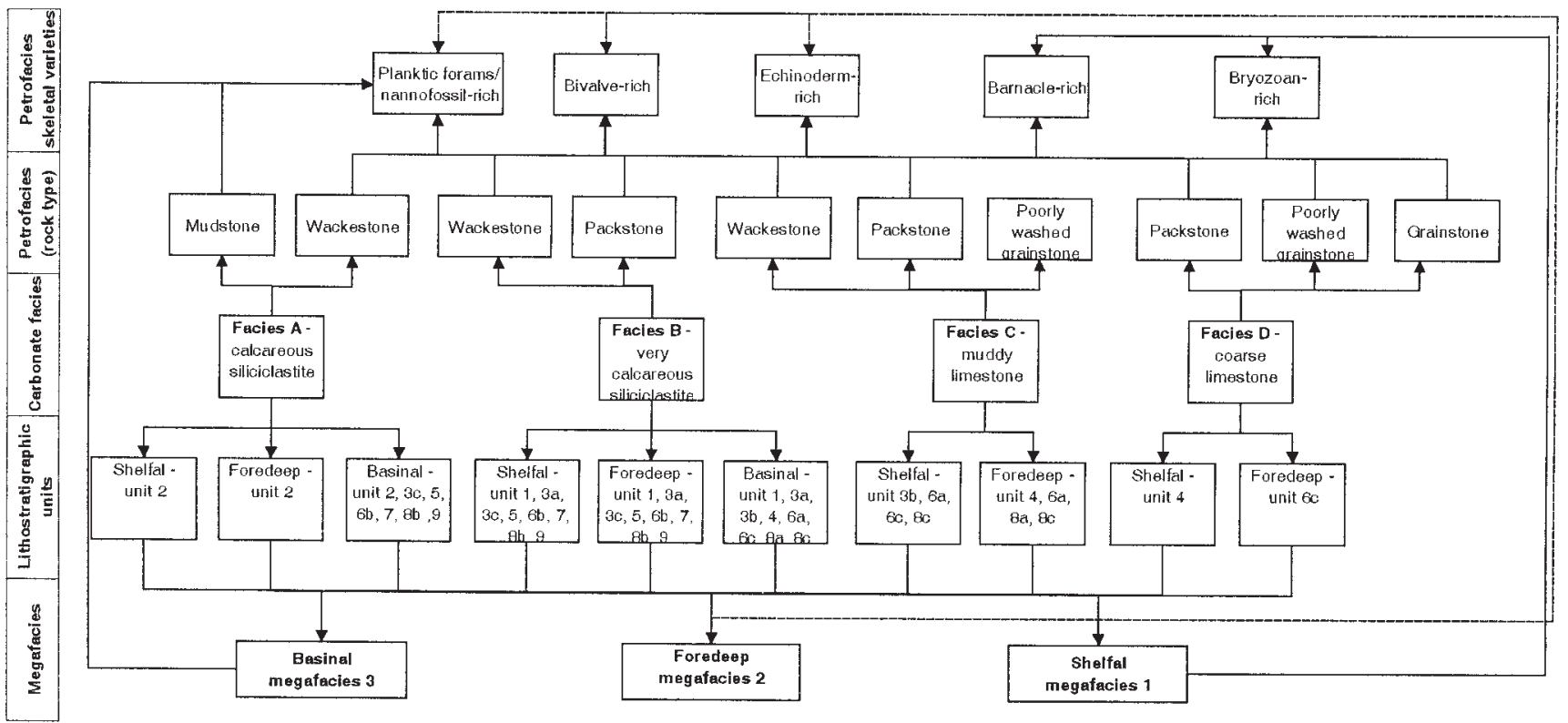

